\title{
THE POSITIONAL-RISK DOCTRINE IN WORKMEN'S COMPENSATION
}

BY

\section{ARTHUR LARSON*}

The "positional-risk" doctrine in workmen's compensation may be stated as follows: An injury "arises out of" the employment if it would not have occurred but for the fact that the conditions or obligations of the employment placed claimant in the position where he was injured by a neutral force, meaning by "neutral" neither personal to the claimant nor distinctly associated with the employment. A classic, if somewhat archaic, set of facts illustrating the doctrine is supplied by the New Jersey case of Gargiulo v. Gargiulo. ${ }^{1}$ A butcher's helper, on his way to empty trash, was struck in the eye by a stray arrow shot into the air by a child in the neighborhood. The New Jersey Supreme Court, in awarding compensation, said:

It [the employment] brought him unwittingly into the line of fire of the arrow, where he would not have been except for his employment. But for the compliance with his allotted work directive requiring his presence at the particular time and place in question, the injury would not have been inflicted. ${ }^{2}$

This doctrine, whose origins seem to go back at least as far as $1927,{ }^{3}$ can by no means claim majority rule status, but it has been accepted in at least some factual categories by an impressive and growing

Copyright 1973 by Duke University Law School, reprinted by permission of the author and publisher from 1973 Duke University Law Journal 761.

* Professor of Law and Director of Rule of Law Research Center, Duke University School of Law. A.B. 1931, L.L.D. 1953 Augustana College; M.A. (Juris.) 1938, D.C.L. 1957, Oxford University.

1. 13 N.J. 8, 97 A.2d 593 (1953).

2. Id. at 13,97 A.2d at 596 .

3. What appears to be the earliest statement of the positional risk principle as a general doctrine occurs in the Colorado case of Aetna Life Ins. Co. v. Industrial Comm'n, 81 Colo. 233, 254 P. 995 (1927). See text accompanying notes 19-22 infra. 
number of jurisdictions. The purpose of this article is to show, by drawing on a wide assortment of apparently unrelated categories, that there can and should be recognized a universal and pervading causal principle along the lines just described as the positional-risk doctrine, and to demonstrate further that, once a jurisdiction has adopted the doctrine in one category, it should logically extrapolate it to every type of neutral-risk case presenting the question of causal relation between the injury and the employment.

The doctrine has potential applicability in practically every jurisdiction, in spite of some variations in the statutory backdrop. Fortytwo states, and the Longshoremen's and Harbor Workers' Compensation Act, ${ }^{4}$ have adopted the entire British Compensation Act formula: injury "arising out of and in the course of employment." One state, Utah, changed it to "arising out of or in the course of employment." As to variants on the "arising out of" portion, West Virginia preferred "resulting from"; ' Wyoming substituted the phrase "injuries directly and solely caused by a traumatic accident in the employment"; 8 and North Dakota, ${ }^{9}$ Pennsylvania, Texas, Washington, Wisconsin, and the Federal Employees' Compensation Act omitted the "arising out of" idea altogether. As to the "course of employment" concept, forty-seven states have this phrase; Wisconsin has, instead, the words "[w]here ... performing service growing out of and incidental to his employment"; $;^{10}$ the Federal Employees' Compensation Act ${ }^{11}$ uses the phrase "sustained while in the performance of duty."

\section{The Four Lines of Interpretation OF "ARISING OUt Of"}

To appreciate what a distance compensation decisional law has traveled to reach the positional-risk doctrine, one must review briefly three other lines of interpretation of the "arising" phrase that have figured in this development.

4. 33 U.S.C. $\$ \$ 901-41,944-50$ (1970).

5. See 1 A. Larson, The Law of Workmen's Compensation $\$ 5.20$ (1953).

6. UTAH CODE ANN. \$ 35-1-45 (1953).

7. W. VA. CODE ANN. \$ 23-4-1 (1970).

8. Wro. Stat. ANN. \& 27-49(III) (b) (Cum. Supp. 1971).

9. N.D. CENT. CODE, tit. 65, \& 65-01-02(8) (1960): "Injury' shall mean only. an injury arising in the course of employment ...."

10. Wis. Stat. $\$ 102.03(1)$ (c) (1957).

11. FECA \& 1(a), 5 U.S.C. \& 8102(a) (1970).

Puerto Rico has a formulation of its own: "caused by any act or function inherent in their work or employment, when such accidents happen in the course of said work or employment, and as a consequence thereof." Laws OF P.R. ANN., tit. 11, $\$ 2$ (1962). 
The earliest was the "peculiar-risk" doctrine. Under this doctrine, which in the early dawn of American compensation law was actually the dominant rule, the claimant had to show that the source of the harm was in its nature peculiar to his occupation. Accordingly, even if his work subjected him to a tremendously increased quantitative risk of injury by heat, or cold, or lightning, the claimant might be turned away with the comment that "everyone is subject to the same weather."12 Thus, in Robinson's Case, ${ }^{13}$ a laborer froze his foot while working in the public square all night in very cold weather. The court said: "[T] greater risk of freezing his foot than the ordinary person engaged in outdoor work in cold weather."14 But, of course, the ordinary person is not engaged in outdoor work in cold weather; and so to limit the comparison was to rob the claimant's employment of the only distinctive feature it had for present purposes.

The peculiar-risk test gradually achieved a well-deserved oblivion, and was replaced by the increased-risk test. This test differs from the peculiar-risk test in that the distinctiveness of the employment risk can be contributed by the increased quantity of a risk that is qualitatively not peculiar to the employment.

The increased-risk test is still the prevalent test in the United States today, and, even in states that have accepted the positional-risk doctrine, a prudent lawyer will, in a lightning case for example, begin by trying to prove that the employment increased the risk of exposure to lightning by placing claimant on a height, or near metal, or in contact with an element that conducts electricity. ${ }^{15}$

The next stage may be called the "actual-risk" doctrine. Under this doctrine, a substantial number of courts are saying, in effect, "we do not care whether this risk was also common to the public, if in fact it was a risk of this employment."18 It is a more defensible rule than the preceding one, since there is no real statutory basis for insisting

12. See 1 A. LARSON, The LAW OF WORKMEN's COMPENSATION $\$ 6.20$ (1953).

13. 292 Mass. 543,198 N.E. 760 (1935).

14. Id. at 546,198 N.E. at 761 .

15. For a typical increased-risk lightning award, see Bauer's Case, 314 Mass. 4, 49 N.E.2d 118 (1943). The increased risk included presence on top of an exposed hill, wet clothes, and nearness to an iron bed and electrical wiring.

16. The leading actual-risk case is Hughes v. Trustees of St. Patrick's Cathedral, 245 N.Y. 201, 156 N.E. 665 (1927), which involved a section boss who suffered heat prostration while working in a cemetery. The essence of the opinion of the New York Court of Appeals is summed up in one sentence: "Although the risk be common to all who are exposed to the sun's rays on a hot day, the question is whether the employment exposes the employee to the risk." Id. at 202-03, 156 N.E. at 665 . 
upon a peculiar or increased risk, as long as the employment subjected claimant to the actual risk that injured him.

The most advanced causal rule is the "positional-risk" doctrine summarized in the opening sentence. It should be particularly noted, in the phrasing of the doctrine, that the essence of the positional-risk doctrine is that the source of harm be a "neutral" one. This point is best approached by stressing that there are three categories of risk for present purposes: distinctly occupational; distinctly personal; and neutral-i.e., risks having no particular personal or employment character.

The occupational-risk group comprises all the obvious kinds of injury that one thinks of at once as industrial injury. All the things that can go wrong around a modern factory, mill, mine, transportation system, or construction project-machinery breaking, objects falling, explosives exploding, tractors tipping, fingers getting caught in gears, excavations caving in, and so on-are clearly in this category and constitute the bulk of what not only the public but perhaps also the original draftsmen of compensation acts had in mind as their proper concern. Equally obviously associated with the employment, however, are also the occupational diseases, which, as the very name implies, are produced by the particular substances or conditions inherent in the environment of the employment. As far as the "arising" test is concerned, this group causes no trouble, since all these risks fall readily within the increased-risk test and are considered work-connected in all jurisdictions.

At the other extreme are origins of harm so clearly personal that, even if they take effect while the employee is on the job, they could not possibly be attributed to the employment. If the time has come for the employee to die a natural death, or to expire from the effects of some disease or internal weakness of which he would as promptly have expired whether he had been working or not, the fact that his demise takes place in an employment setting rather than at home does not, of course, make the death compensable. Or if the employee has a mortal personal enemy who has sworn to seek him out wherever he may be, and if this enemy happens to find and murder the employee while the latter is at work, the employment cannot be said to have had any causal relation to the death. ${ }^{17}$ The same is true if the employee, for reasons of his own, carries a bomb in his bosom (as actually happened in one case $^{18}$ ), and if the bomb goes off during business hours.

17. See 1 A. LARSON, THE LAW OF WORKMEN's COMPENSATION $\$ 11.21$ (1972).

18. Bogavich v. Westinghouse Elec. \& Mfg. Co., 162 Pa. Super. 388, 57 A.2d 598 (1948). 
Between these two areas lies the third: that of risks of neither distinctly employment nor distinctly personal character. Illustrations of this category may be drawn from a wide variety of controversial cases. A man hard at work in the middle of a factory yard may be hit by a stray bullet out of nowhere, bitten by a mad dog, stabbed by a lunatic running amuck, struck by lightning, thrown down by a hurricane, killed by an enemy bomb, injured by a piece of tin blown from someone's roof, shot by a child playing with an air rifle, murdered as a result of mistaken identity, felled by debris from a distant explosion, or blinded by a flying beetle. Another kind of neutral-risk case is that in which the cause itself, or the character of the cause, is simply unknown. An employee may be found to have died on the job from unexplained causes, or he may suffer a slip or fall for no reason that anyone, including himself, can explain. An employee may be attacked by unknown persons, whose motives may have been personal or related to the employment.

There are thus three categories of risk; but unfortunately, there are only two places where the loss may fall-on the employer or on the employee. And so the question becomes, who bears the burden of this in-between category of harms?

The usual answer in the past has been to leave this loss on the employee, on the theory that he must meet the burden of proof of establishing affirmatively a clear causal connection between the conditions under which he worked and the occurrence of the injury. More recently, some courts have reasoned in the following vein: Either the employer or the employee must bear the loss; to show connection with the employment, there is at least the fact that the injury occurred while the employee was working; to show connection with the employee's personal life there is nothing; therefore, although the work connection is slender, it is at least stronger than any connection with the claimant's personal life.

\section{Specific Applications of the Positional-Risk Test}

\section{Lightning}

With these theoretical considerations identified, the particular factual applications of the positional-risk doctrine may now be reviewed. Since the first application of the rule ${ }^{19}$ seems to have been in a lightning

19. See note 3 supra. 
case, this category is an appropriate place to begin. In Aetna Life Insurance Co. v. Industrial Commission, ${ }^{20}$ decided in 1927, the Supreme Court of Colorado was confronted with a textbook positionalrisk situation: A farm hand was killed by lightning while driving a team of horses without a wagon. The effect of the decision was summarized in a concurring opinion as follows:

[W] hen one in the course of his employment is reasonably required to be at a particular place at a particular time and there meets with an accident, although one which any other person then and there present would have met with irrespective of his employment, that accident is one "arising out of" the employment of the person so injured. ${ }^{21}$

The court did not seem to be aware of the historic significance of its brief opinion, as indicated by the following additional passage from the court's opinion by Denison, J.:

A majority of the court thinks that, since Oakley's employment required him to be in a position where the lightning struck him, there was a causal relation between employment and accident, so that the latter may be said to arise out of the former and therefore the judgment should be affirmed. The writer, however, is of the opinion, in which the Chief Justice concurs, that the mere fact that duty calls the employee to the place where he is killed or injured, is not enough; yet recognizes that the precedents in this state and in the Supreme Court of the United States extend even beyond limits which would include the present case and so concurs in the result reached by the majority. ${ }^{22}$

The court adduced no Supreme Court cases, but cited three Colorado cases: Industrial Commission v. Pueblo Auto Co., ${ }^{23}$ Industrial Commission v. Hunter, ${ }^{24}$ and State Compensation Insurance Fund $v$. Industrial Commission. ${ }^{25}$ It is curious that the court felt bound by these three cases (each of which involved criminal attacks by highwaymen upon traveling employees, and which therefore could easily have been explained and distinguished on increased-risk grounds) to state a sweeping positional-risk rule designed to cover a case with no increasedrisk component at all. For whatever reason, the decision opened the door to the positional-risk era.

Beyond this early example, there has been only one application of the doctrine to a lightning case, and that does not appear to have sur-

20. 81 Colo. 233, 254 P. 995 (1927).

21. Id. at $236,254 \mathrm{P}$. at 996 .

22. Id. at $234,254 \mathrm{P}$. at 995 .

23. 71 Colo. 424,207 P. 479 (1922).

24. 73 Colo. 226,214 P. 393 (1923).

25. 80 Colo. 130, 249 P. 653 (1926). 
vived. In E.I. Du Pont de Nemours Co. v. Lilly, ${ }^{26}$ a lightning case, the Appellate Court of Indiana abandoned the increased-risk test and applied the positional-risk test, in the following language:

[H]e would not have been on the transfer platform proceeding along the platform in the direction of the shelter house at the particular time and at the particular place where he was when struck by the bolt of lightning except for the duties and place of his employment and the specific instructions and orders of his employer . . . . ${ }^{27}$

Subsequently, however, the Supreme Court of Indiana, while affirming the Lilly case, chose to do so on the ground that there was evidence on which a finding of increased hazard could properly be made. ${ }^{28}$ The court did not criticize or disavow the positional theory, and it cited Burroughs Adding Machine Co. v. Dehn, ${ }^{29}$ which had first announced the positional-risk doctrine in Indiana in an unexplained-fall case, without disapproval; but whether its decision is to be construed as indicating an aversion to the theory, as the appellate court assumed in a later lightning case, ${ }^{30}$ or whether it means only that it did not propose to take such a step in a case which could be disposed of on more conventional grounds, remains to be seen. The Supreme Court of Indiana has not been heard from on the precise point, but in the meantime the appellate court is proceeding on the assumption that its brief excursion into positional-risk territory is a thing of the past. Thus, in Crites v. Baker, ${ }^{32}$ the appellate court, while affirming compensation to a garbage truck driver struck by an apple thrown from a school bus, continued its policy of assuming that increased risk must be shown in Indiana. Since the appellate court gave us Dehn and Lilly, presumably the appellate court can take them away-even though the reason seems to be an unduly broad implication from the supreme court's opinion affirming Lilly.

\section{Tornadoes and windstorms}

Two states, Louisiana and Michigan, have adopted the positionalrisk test in tornado cases.

Of the two, Louisiana's acceptance of this rule was much the earlier, having been announced in 1942. In awarding compensation to an employee in a cottonseed mill which collapsed during a cyclone, the court suggested that the decision might perhaps rest on the employment

26. 75 N.E.2d 796 (Ind. App. 1947), aff'd, 226 Ind. 267, 79 N.E.2d 387 (1948).

27. 75 N.E.2d 796, 798.

28. E.I. DuPont de Nemours Co. v. Lilly, 226 Ind. 267, 79 N.E.2d 387 (1948).

29. 110 Ind. App. 483, 39 N.E.2d 499 (1942).

30. Citizens Indep. Tel. Co. v. Davis, 120 Ind. App. 20, 94 N.E.2d 495 (1950).

31. 276 N.E.2d 582 (Ind. App. 1971). 
risk resulting from the heavily loaded condition of the building, but it said:

We prefer to place our decision on what we believe to be a sound footing, that is-that the deceased, by reason of his employment, was required to be in a building which fell upon him; that his death was due to the fact that his employment necessitated that he be at the place where the accident occurred . . . . ${ }^{32}$

Michigan arrived at a similar point twenty-eight years later, and somewhat less effortlessly, in its 4-to-3 decision in Whetro v. Awkerman. ${ }^{33}$ This case dealt with two separate claimants, one of whom was killed and the other injured, at separate localities, but both as the result of a tornado. Rejecting the contact-with-the-premises exception, ${ }^{34}$ the

32. Harvey v. Cađdo De Soto Cotton Oil Co., 199 La. 720, 731, 6 So. 2d 747, 751 (1942). The court also quoted the following significant language from the earlier case of Kern v. Southport Mill, 174 La. 432, 437-38, 141 So. 19, 21 (1932), a streetrisk case:

By which [arising out of the employment] is meant, that the accident must be the result of some risk to which the employee is subjected in the course of his employment and to which he would not have been subjected had he not been so employed.

But time, place, and circumstances must determine this. When the illfated Titanic foundered in the spring of 1912, all persons aboard her were situated exactly alike as to time and place; but they were not all situated alike as to circumstance. Those who traveled for pleasure were present of their own free choice alone; those who traveled for business, whether their own or that of another, were there of necessity. And, when one finds himself at the scene of an accident, not because he voluntarily appeared there but because the necessities of his business called him there, the injuries he may suffer by reason of such accident 'arise out of' his employment, if it so be that he was employed and his employment required him to be at the place of the accident at the time when the accident occurred.

..

The question whether or not the employee might have been injured in the same way, and even at the same place and time had he not been called there by the necessities of his employer's business, but had gone there only for his own pleasure or in pursuit of his own business, has nothing whatever to do with the case. $199 \mathrm{La}$. at 730,6 So. $2 d$ at 750 .

33. 383 Mich. 235,174 N.W.2d 783 (1970).

34. The contact-with-the-premises exception, which has been accepted in some form by a number of courts, may be phrased as follows: Although the original force, such as hurricane, lightning, or earthquake, did not arise out of the employment under the increased-risk test, the injury may be compensable to the extent that it results from physical contact, produced by that force, with some part of the working environment. In less abstract terms, while claimant cannot recover for the effects of the direct impact of the tornado on him, he can recover if the tornado blows down a wall which in turn falls on him. The leading American authority for this rule is Caswell's Case, 305 Mass. 500, 26 N.E.2d 328 (1940), a product of the New England hurricane of 1938. Claimant was working in a mill of stout brick construction at the time the hurricane struck. Buildings of all kinds in the area were destroyed. The force of the wind broke in the windows, lifted the roof, and disintegrated the wall, with the result that claimant was crushed by bricks and debris. The court adopted the following rule from the leading English case of Brooker v. Thomas Borthwick and Sons, [1933] A.C. 669, in which a wall fell on the employee during an earthquake: 
court held that it was not necessary to establish a proximate causal relationship between the employment and injury in order to establish compensability, and specifically rejected the "Act of God" defense. Affirming awards of compensation, the court simply stated that the employee's employment was in each case the occasion for his injury, and that therefore the injuries were compensable. This case appears to adopt the positional-risk doctrine generally for the state of Michigan. The court begins by conceding that the earlier lightning cases in Michigan were inconsistent with this result. ${ }^{35}$ It also agreed that no distinction was justified between lightning cases and tornado cases. Moreover, it declined to evade the central issue by resort to the contact-with-thepremises exception, upon which the court below had relied. It traced the evolution of "arising" cases in Michigan, with an exhaustive compilation of cases, including the increased-risk, street-risk, and on-thepremises cases, and concluded: "They have brought the law in Michigan to the point where it can be said today that if the employment is the occasion of the injury, even though not the proximate cause, compensation should be paid."36

The court then traced the parallel evolution of the English and Massachusetts cases from the proximate cause era to the positional-risk era and placed Michigan firmly in the same company.

Brennan, C.J., dissented, joined by Dethmers, J., and Kelly, J., in a brief and superficial opinion. The dissenters displayed as the centerpiece of their argument the equating of acts of God with privatelymotivated assaults:

An adulterous cobbler shot at his last by his jealous wife may be "in the course of" his employment. But the injury does not "arise out of" the job. On what basis of moral responsibility should his injuries be paid for by his employer?...

If a workman is injured by some natural force such as lightning, the heat of the sun, or extreme cold, which in itself has no kind of connection with employment, he cannot recover unless he can sufficiently associate such injury with his employment. This he can do if he can show that the employment exposed him in a special degree to suffering such an injury. But if he is injured by contact physically with some part of the place where he works, then, apart from questions of his own misconduct, he at once associates the accident with his employment and nothing further need be considered. So that if the roof or walls fall upon him, or he slips upon the premises, there is no need to make further inquiries as to why the accident happened. Per Lord Atkin. [1933] A.C. at 677 .

35. The court cited and overruled Kroon v. Kalamazoo County Rd. Comm'n, 339 Mich. 1, 62 N.W.2d 641 (1954); Nelson v. Country Club, 329 Mich. 479, 45 N.W.2d 362 (1951); Thier v. Widdifield, 210 Mich. 355, 175 N.W. 16 (1920); Klawinski v. Lake Shore \& Mich. S. Ry., 185 Mich. 643, 152 N.W. 213 (1915).

36. Whetro v. Awkerman, 383 Mich. 235, 243, 174 N.W.2d 783, 786 (1970). 
Lightning, flood, tornadoes and estranged wives will always be with us, in this vale of tears. ${ }^{37}$

The legal concepts in this dissent are as archaic as its cobbler example. Leaving aside the astonishing premise that workmen's compensation liability is based on the employer's "moral responsibility," one wonders how it is possible that in seventeen years the basic distinction between neutral risks like tornadoes, and personal risks like privately motivated assaults, can have failed to come to the attention of three members of the Supreme Court of Michigan. ${ }^{38}$

The "swing vote" in this historic decision was somewhat reluctantly cast by Black, J., who agreed in a concurring opinion that the result was right and that the overruled cases were "quite unsound," but was troubled by the jolt to stare decisis represented by the overruling of a long series of established decisions. He joined the majority, however, and cast his vote consistent with theirs, in order to produce a working rule instead of having a court "fractured into indecisive groups."

\section{Stray bullets and flying debris}

One of the early attempts to soften the traditional increased-risk test took the form of the "street-risk" exception, which, in its most advanced form, contributed the idea that a harm resulting from risks of the street should be compensable whether or not this particular claimant's exposure to street risks was unusually great. In other words, if the employment occasions the employee's use of the street, the risks of the street are the risks of the employment, and, as was stated in the leading case establishing this rule, Dennis v. A.J. White \& Co.," "it is quite immaterial whether the nature of the employment involves continuous or only occasional exposure to the dangers of the street."40

The street-risk doctrine, which originally grew up around perils commonly associated with iravel along the street, such as highway accidents and slips on icy sidewalks, has been expanded to include almost any source of danger actually encountered in the street. In a case involving a chauffeur stabbed by a roving madman, the New York Court of Appeals painted this Hogarthian picture of the city street and its perils:

37. Id. at 244,174 N.W.2d at 787.

38. The figure of seventeen years is based on the fact that the doctrine of "positional risk" as applied to and limited to "neutral risks" was first expounded in the original edition of A. LARSON, THE LAW OF WORKMEN's COMPENSATION (1953).

39. [1917] A.C. 479 (H.L.).

40. Id. at 483 . 
The street becomes a dangerous place when street brawlers, highwaymen, escaping criminals or violent madmen are afoot therein as they sometimes are. The danger of being struck by them by accident is a street risk because it is incident to passing through or being on the street. when dangerous characters are abroad.

Particularly on the crowded streets of a great city, not only do vehicles collide, pavements become out of repair and crowds jostle, but mad or biting dogs may run wild, gunmen may discharge their weapons, police officers may shoot at fugitives fleeing from justice, or other things may happen from which accidental injuries result to people on the streets which are peculiar to the use of the streets and do not commonly happen indoors. ${ }^{41}$

On this reasoning, the concept of street risk has been deemed broad enough to include stray bullets, ${ }^{42}$ a bomb dropped in Wall Street, ${ }^{43}$ or even placed in a plane, ${ }^{44}$ portions of roofs or buildings fall-

41. Katz v. A. Kadans \& Co., 232 N.Y. 420, 422, 134 N.E. 330,331 (1922). Contra Liebman v. Colonial Baking Co., 391 S.W.2d 948 (Mo. Ct. App. 1965). Claimant was employed as a delivery man for a bakery company. While making a delivery he was assaulted by a drunken stranger. After a detailed discussion of assault rules and various street-risk theories, the court held that the fact that this assault occurred in the street was merely incidental, and as a result the normal assault rule should apply, rather than the street-hazard doctrine. Since this was a neutral assault, the injury was not compensable.

42. Frigidaire Corp. v. Industrial Accident Comm'n, 103 Cal. App. 27, 283 P. 974 (1929); Greenberg v. Voit, 250 N.Y. 543, 166 N.E. 318 (1929); Santos v. Guemes, 270 App. Div. 1057, 63 N.Y.S.2d 61, appeal denied, 296 N.Y. 1061, 69 N.E.2d 565 (1946).

The contra case of Borgeson v. Industrial Comm'n, 368 IIl. 188, 13 N.E.2d 164 (1938), in which a salesman was hit by a bullet directed by a man toward a woman and in which it was held this was not a "risk or hazard of traffic or transportation," and that "any loiterer there was exposed to the same risk," was disapproved in C.A. Dunham Co. v. Industrial Comm'n, 16 Ill. 2d 102, 156 N.E.2d 560 (1959), to the extent that it held that street risks included only traffic and transportation hazards, and not such risks as stray bullets and bombs.

The contra case of Lexington Ry. Sys. v. True, $276 \mathrm{Ky}, 446,124$ S.W.2d 467 (1939), holding that the risk of a streetcar motorman being struck by a bullet fired by a boy shooting at birds was not a risk peculiar to the street, was expressly overruled in Corken v. Corken Steel Prods., Inc., 385 S.W.2d 949 (Ky. 1965), in which compensation was awarded for the death of a salesman who was deliberately shot without provocation by a stranger as the salesman was attempting to get back into his automobile to continue making calls on customers.

43. Roberts v. Newcornb \& Co., 234 N.Y. 552, 138 N.E. 443 (1922).

44. C.A. Dunham Co. v. Industrial Comm'n, 16 Ill. 2d 102, 156 N.E.2d 560 (1959). The deceased was killed in an airplane crash which was caused by the explosion of a bomb placed aboard by the son of a passenger to collect insurance on his mother's death. The court said that since the deceased's work required him to travel by air, "the plane became the milieu of his employment, and the hazard of a plane crash became a risk of that employment, to which decedent was subjected because of 
ing in a windstorm, ${ }^{45}$ trees falling on the highway, ${ }^{46}$ a shot by a sentry whose challenge was not heard by a taxi driver, ${ }^{47}$ a brick thrown by a small boy, ${ }^{48}$ a stabbing by a lunatic, ${ }^{49}$ a toy torpedo thrown by a child, ${ }^{50}$ and footballs ${ }^{51}$ and baseballs ${ }^{52}$ flying into the street.

As the boundaries of the street-risk concept have been stretched to embrace stray bullets, falling cornices, and homicidal maniacs, dissatisfaction has been felt with the artificiality of limiting such holdings to mishaps whose situs happens to be a public street. It has been observed that injury from stray bullets in a public street may be compensable as a street risk. ${ }^{53}$ In Auman v. Breckiniridge Telephone Co., ${ }^{54}$ however, the claimant was crossing not a public street but a vacant lot between a garage and his office building when he was struck by a stray bullet. The Minnesota court, citing and apparently accepting the New York stray-bullet cases, nevertheless denied compensation on the technical ground that the vacant lot was not a public way and did not come within the street-risk doctrine.

The best example of the impossibility of confining a principle of liability in terms of an arbitrary situs such as the public street is seen in the story of the New York stray-bullet cases. The risk of being hit by stray bullets from the guns of gangsters, or of police pursuing fugitives, was listed as a "street risk" in Katz v. Kadans;" ${ }^{55}$ and, although we know from the cinema that gunmen may discharge their weapons indoors as well as outdoors and that cops-and-robbers chases may take place anywhere-inside buildings, over rooftops, through the sewers, in and out of boudoirs, or through the frozen wilderness-still, one might concede for the sake of argument that the risk of random bullets

the fact that he was directed to travel by plane." In another part of the opinion there is language indicating that the claim could be sustained on the theory of street risk. The death was held compensable.

45. Scandrett v. Industrial Comm'n, 235 Wis. 1, 291 N.W. 845 (1940).

46. Globe Indem. Co. v. MacKendree, 39 Ga. App. 58, 146 S.E. 46 (1928), aff'd, 169 Ga. 510, 150 S.E. 849 (1929); Le Vasseur v. Allen Elec. Co., 338 Mich. 121, 61 N.W.2d 93 (1953).

47. Thorn v. Humm \& Co., 112 L.T.R. (n.s.) 888 (1915).

48. Good v. City of Omaha, 125 Neb. 307, 250 N.W. 61 (1933).

49. Katz v. A. Kadans \& Co., 232 N.Y. 420,134 N.E. 330 (1922).

50. Town of Lindsay v. Sawyer, 156 Okla. 32, 9 P.2d 30 (1932).

51. Friel v. Industrial Comm'n, 398 Ill. 361, 75 N.E.2d 859 (1947). A football shattered glass and injured a streetcar motorman.

52. Perkins v. Sprott, 207 N.C. 462, 177 S.E. 404 (1934). A baseball smashed a windshield injuring a truck driver.

53. See note 42 supra.

54. 188 Minn. 256, 246 N.W. 889 (1933).

55. See note 41 supra. 
is somewhat greater in the street than elsewhere. But this "street risk" did not remain out in the street. The first step was up the front steps, when compensation was awarded for the death of a janitor who, while sweeping the front stoop, was killed by random bullets from the car of passing gangsters. ${ }^{56}$ It then moved indoors, when a barber in the interior of a building, hit by a stray bullet from a street fight, was granted compensation because the barber shop, being on the ground floor, was exposed to such risks as this. ${ }^{57}$

So far, the street has been brought in the front door and as far as the ground floor. For the time being, one can only wait until somebody sitting beside a second-floor window gets hit by a stray bullet from the street, and, if the appropriate cases will arise, perhaps the risks of the street can work their way up the side of the building as far as the full range of side arms. Would the New York court be able to draw distinctions between the ground floor, the second floor, and the twentieth floor, when everyone knows that stray bullets go up as well as sideways?

In actual fact, New York has made several awards, usually in memorandum decisions, for injuries by random bullets in which the street-risk doctrine could not conceivably have been invoked. In the Christiansen $^{68}$ case, the deceased had made an appointment to meet a man in a tavern on business. While waiting for him to arrive, deceased was drinking at the bar. At this point a complete stranger began shooting at random in the barroom. With no reference to street risks or any other special kind of risks, the court held this hazard to be a hazard of the employment and awarded compensation, and leave to appeal was denied by the highest court of New York. In three other cases, employees have been struck by random accidental shots within their own employer's buildings, in two instances by policemen, ${ }^{59}$ and in one by a third person, ${ }^{60}$ and compensation has been consistently awarded. Therefore, although New York has never in so many words announced that it will not be confined to the street in stray-bullet cases, the record speaks for itself, and shows awards for stray bullets encountered in de-

56. Greenberg v. Voit, 250 N.Y. 543,166 N.E. 318 (1929).

57. Santos v. Guemes, 270 App. Div. 1057, 63 N.Y.S.2d 61, appeal denied, 296 N.Y. 1061,69 N.E.2d 565 (1946).

58. Christiansen v. Hill Reprod. Co., 262 App. Div. 379, 29 N.Y.S.2d 24 (1941), aff'd, 287 N.Y. 690,39 N.E.2d 300 (1942).

59. Hall v. Feldman \& Sons, 262 App. Div. 979, 30 N.Y.S.2d 70, appeal denied, 287 N.Y. 854, 38 N.E.2d 390 (1941); Entrocut v. Paramount Bakery \& Rest. Co., 222 App. Div. 844, 226 N.Y.S. 808 (1928) (mem.).

60. Groppe v. J.C. Penney, 272 App. Div. 851, 70 N.Y.S.2d 173 (mem.), appeal denied, 297 N.Y. 1035, 74 N.E.2d 486 (1948). 
partment stores, ${ }^{61}$ junkyard offices, ${ }^{62}$ restaurants, ${ }^{63}$ bars, ${ }^{64}$ and barber shops. ${ }^{65}$

California, confronted with the identical problem, met it by discarding the street-versus-nonstreet distinction and adopting the positional-risk doctrine. California had a background of precedents in which compensability for stray bullets had turned on the difference between a locale such as a railway platform, ${ }^{66}$ as against a ranch, ${ }^{67}$ an orange grove, ${ }^{68}$ or a restaurant. ${ }^{69}$ Occasionally an award had been based on a theory that the nature of the work or setting increased the random-bullet risk. Thus, such a danger was held obviously increased for an employee whose duties consisted of patrolling a ranch for poachers and assisting in deer hunting. ${ }^{70}$ Much less obvious was the increased risk in the General Accident case. ${ }^{71}$ In this case, the employee was repairing tires in his employer's garage when an altercation broke out between his employer and two customers. The employer fired a shot, apparently at one of the customers, which ricocheted and hit the employee, who had taken no part whatever in the episode. The court justified its award with this comment:

[I] $\mathrm{t}$ can fairly be said that to some extent the risk of shooting, holdups, assaults, and the like has in recent years become so closely associ-

\section{Id.}

62. Hall v. Feldman \& Sons, 262 App. Div. 979, 30 N.Y.S.2d 70, appeal denied, 287 N.Y. 854,38 N.E.2d 390 (1941).

63. Entrocut v. Paramount Bakery \& Rest. Co., 222 App. Div. 844, 226 N.Y.S. 808 (1928) (mem.).

64. Christiansen v. Hill Reprod. Co., 262 App. Div. 379, 29 N.Y.S.2d 24, aff'd, 87 N.Y. 690,39 N.E.2d 300 (1941).

65. Santos v. Guemes, 270 App. Div. 1057, 63 N.Y.S.2d 61, appeal denied, 296 N.Y. 1061, 69 N.E.2d 565 (1946). In the light of the general development of New York doctrine in the causation area, the 1931 decision in Lebeda v. Pongracz, 230 App. Div. 606, 246 N.Y.S. 293, aff'd, 256 N.Y. 560, 177 N.E. 140 (1931), which denied compensation to a watchman hit by a bullet fired by New Year's revelers whom he was watching through the window, appears to be obsolete. The court relied on the specialrisk test, which has since been disavowed in New York.

66. Frigidaire Corp. v. Industrial Accident Comm'n, 103 Cal. App. 27, 283 P. 974 (1929).

67. Associated Indem. Corp. v. Industrial Accident Comm'n, 43 Cal. App. 2d 292, 110 P.2d 676 (1941); cf. Trucks Ins. Exch. v. Industrial Accident Comm'n, 147 Cal. App. 2d 460, 305 P.2d 55 (1957), awarding compensation on similar facts in 1957, and indicating that the Associated Indemnity case had been overruled by a succession of subsequent cases.

68. Hicks v. White, 18 I.A.C. 80.

69. Travelers Ins. Co. v. Moon Chin, 12 I.A.C. 150.

70. O.L. Shafter Estate Co. v. Industrial Accident Comm'n, 175 Cal. 522, 166 P. 24 (1917).

71. General Accident Fire \& Life Assur. Corp. v. Industrial Accident Comm'n, 186 Cal. 653, 200 P. 419 (1921). 
ated with the garage business that it may be said that employment in such an industry is hazardous. ${ }^{72}$

Finally, in Industrial Indemnity Co. v. Industrial Accident Commission, ${ }^{73}$ California was faced with exactly the same decision that was presented to New York in the Christiansen ${ }^{74}$ case-what to do about a random shot in a bar. The deceased, who, as co-manager of an inn, sometimes relieved the bartender, was standing at the cash register with her back to the bar when the wife of a customer walked in and fired a shot which was evidently the culmination of an earlier quarrel. The deceased was in no way involved, of course. The bullet ricocheted off the bar and struck the deceased in the back. There was no evidence of any prior shootings or disturbances in the bar. The opinion reviews the various devices that had been used in the past to extend liability without parting with earlier causation theories. For example, it observed that the General Accident ${ }^{75}$ reasoning could be pressed into service here: certainly if a garage is the kind of place where bullets may be expected to fly, a bar is no less so. Or, again, the contact-with-thepremises idea could be exploited and extended. Here the court cited explosion ${ }^{70}$ and earthquake ${ }^{77}$ cases that had relied on contact with the premises, and concluded that the real substance of these decisions was that the employment brought the employee into what became a position of danger. However, said the court:

[I]f we desired to follow the specious reasoning in the cases which place liability on the fact that the instrumentality of the employer was the last one in the chain of circumstances leading to the employee's injury, we could say that it was the bar, an instrumentality of the employer, which caused the bullet to ricochet and strike Mrs. Baxter. ${ }^{78}$

Of course, the court knew that this would only be postponing the inevitable decision, since some day, just as a windstorm, explosion, or earthquake might cause injury without any contact with the premises, so a bullet might strike an employee without ricocheting off the employer's property. Accordingly, the opinion swept aside all these dis-

72. Id. at $657,200 \mathrm{P}$. at 421 .

73. 95 Cal. App. 2d 805, 214 P.2d 41 (1950).

74. Christiansen v. Hill Reprod. Co., 262 App. Div. 379, 29 N.Y.S.2d 24 (1941), aff'd, 287 N.Y. 690, 39 N.E.2d 300 (1942). See note 58 supra and accompanying text.

75. General Accident Fire \& Life Assur. Corp. v. Industrial Accident Comm'n, 186 Cal. 653, 200 P. 419 (1921).

76. Pacific Indem. Co. v. Industrial Accident Comm'n, 86 Cal. App. 2d 726, 195 P.2d 919 (1948). (1927).

77. Enterprise Dairy Co. v. Industrial Accident Comm'n, 202 Cal. 247, 259 P. 1099

78. 95 Cal. App. $2 \mathrm{~d}$ at $811-12,214$ P.2d at 46. 
tinctions and announced a simple formula: "It is only necessary to hold that the death of Mrs. Baxter arose out of her employment because her employment required her to be in what turned out to be a place of danger." 79

In New York, very nearly the same rule prevails. However, it is characteristic of compensation law in New York that it is built up largely not by long opinions of the Court of Appeals analyzing and coordinating controversial legal principles, but by hundreds of memorandum opinions dealing with the facts of particular cases. These must be carefully pieced together in a sort of mosaic, before the pattern is discernible.

The last time the Court of Appeals did any theorizing about the present problem, it announced what might be called the zone-of-danger theory. In the Filitit ${ }^{80}$ case, claimant, working in the open near the edge of his employer's property was struck by a falling piece of cornice from a building on adjoining property. Compensation was awarded on the reasoning that the employment brought claimant into a "zone of danger." The court had to distinguish the earlier McCarter case, ${ }^{81}$ which had denied compensation to an employee injured by the explosion of an old shell on neighboring property, and which at the same time had expiicitly rejected the positional-risk test. ${ }^{82}$ It attempted to do so by saying that the risk from the explosion was general, since the fragments covered a wide area and imperilled many people, while in the Filitti case there was a small and identifiable zone of danger.

The $M c$ Carter case seems to have been weakened considerably by a subsequent case also involving an explosion on adjoining property. ${ }^{83}$ This time, however, instead of a direct hit, there was a collapse of the wall of the adjoining building, which fell onto the roof of the premises where the employee was at work. The award was upheld by the Court of Appeals in a memorandum opinion, on the authority of the Filitti case, with no mention of the McCarter precedent. Apparently one must conclude, after all, that the area within range of explosions on

79. Id. at 812,214 P.2d at 46.

80. Filitti v. Lerode Homes Corp., 244 N.Y. 291, 155 N.E. 579 (1927).

81. McCarter v. LaRock, 240 N.Y. 282, 148 N.E. 523 (1925). A similar case on the facts is Cennell v. Oscar Daniels Co., 203 Mich. 73, 168 N.W. 1009 (1918), denying compensation for injury due to explosion of refuse being dumped by the public scavenger, since the dumping endangered the general public equally.

82. "[W]e have insisted that there must be some connection between accident and employment other than a mere physical location of the employment which placed him in the pathway of a cause producing injuries, no matter how or where that cause originated." 240 N.Y. at 285,148 N.E. at 524.

83. Malena v. Leff, 265 N.Y. 533, 193 N.E. 307 (1934). 
neighboring premises is a zone of danger. When, to this case, one adds all the random-bullet cases in which awards have been obtained, it becomes evident that the net result in New York is very little different from that in California under an avowed positional-risk theory. ${ }^{84}$

New York fully accepts the actual-risk doctrine, and, in fact, was probably the first to announce it in an exposure case. ${ }^{85}$ Now, it is a very short step from the actual-risk to the positional-risk theory, if, in determining the existence of actual risk, one takes a retrospective view. If a stenographer is sitting by an open window on the third floor of a business building, and is struck by a stray bullet, a court could, under the actual-risk test, look back and conclude that, as the event itself proved, the risk of stray bullets was indeed a risk of that employment. This, after all, is precisely the process that took place when courts decided that random bullets were a risk of being a barber or a tire repairman in a garage. Similarly, in the Filitti case, ${ }^{86}$ one can look back at the event and say, "Yes, as it turned out, that defective cornice was a risk of this employment because it created a dangerous area." If this can be said of a cornice, it can be said of any part of any building, inside or out, or of any tree or structure whatever. In short, it can be said of anything that hits an employee because his employment put him in its path. Leaving aside, then, the distinction between big zones of danger caused by explosions and such, and little zones of danger of a more exclusive and private nature-a distinction which seems too arbitrary to survive-one is driven to the conclusion that the New York zone-ofdanger theory, coupled with the state's actual-risk theory, adds up to something very close to the positional-risk doctrine in actual practice.

The New York and California stories have been set out in full because they illustrate the entire process of starting to deal with a typical "neutral" source of harm (stray bullets) by means of a fact-category

84. Several other assorted pieces of the New York mosaic may be mentioned, which help to add up to a positional-risk pattern. In Webster v. Mason, 13 App. Div. $2 d 355,217$ N.Y.S.2d 290 (1961), the employee died from a bee sting. The court did not discuss the theory of risk involved, but merely cited Lepow v. Lepow Knitting Mills, 288 N.Y. 377, 43 N.E.2d 450 (1942). The Lepow case, however, was based on the increased-risk theory because the probability of malaria from a mosquito sting was greater in South Africa. Similarly, an award was made for death from phlebitis migrans from an insect bite in Richmond v. Mass \& Birzt, 275 App. Div. 879, 88 N.Y.S.2d 682 (1949). See also Avis v. Electrolux Corp., 2 App. Div. 2d 717, 151 N.Y.S.2d 542 (1956), in which a salesman's eye was injured by a flying owl's talon, and Monahan v. Remington Rand, Inc., 9 App. Div. 2d 810, 192 N.Y.S.2d 900 (1959), involving a falling tree.

85. See note 16 supra.

86. See text accompanying note 80 supra. 
doctrine (the street-risk doctrine), and ending with the necessity of generalizing the causation principle involved.

Two other states, Massachusetts ${ }^{87}$ and Louisiana, ${ }^{88}$ have made positional-risk awards in stray-bullet cases. And New Jersey, as shown at the outset, has clearly adopted-the positional-risk theory in an indistinguishable case, merely substituting a stray arrow for a stray bullet. ${ }^{s 0}$

\section{Enemy bombs}

There could be no more stark example of a positional risk than the blind destruction wrought by an enemy bomb. At this writing, the continental United States fortunately has not had occasion to develop any law on the subject, since its experience of enemy bombing has been confined to a few Japanese balloon bombs and some desultory shelling by submarines off the West coast, which do not appear to have produced any reported compensation claims. The only bomb cases on record are the so-called Wall Street explosion case, ${ }^{90}$ involving a bomb thrown into the street, and the Dunham case, ${ }^{91}$ involving a bomb planted in an airplane; as has already been related, ${ }^{92}$ the street-risk doctrine was found sufficiently elastic to embrace these sources of injury.

In England, however, there are several cases dating from the First World War. The Second World War produced none, because this type of injury was brought under the Personal Injuries Act of 1939, which supplanted Workmen's Compensation as well as common-law liability for war injuries. ${ }^{93}$ In a world which is never far from a state of war, it may well be worthwhile to examine briefly such case law on the subject as is available.

The English cases, which, it must be remembered, arose rather early in the development of this branch of law, all required proof of

87. Baran's Case, 336 Mass. 342, 145 N.E.2d 726 (1957). Compensation was awarded to an employee who was unintentionally shot while leaving, but still on, employer's premises at the close of the day's work, by a bullet fired by a fifteen-year old engaging in aiming practice.

88. Williams v. United States Cas. Co., 145 So. 2d 592 (La. App. 1962), on facts similar to those in Industrial Indem. Co. v. Industrial Accident Comm'n, 95 Cal. App. 2d 805,214 P.2d 41 (1950).

89. Gargiulo v. Gargiulo, 13 N.J. 8, 97 A.2d 593 (1953).

90. Roberts v. Newcomb \& Co., 234 N.Y. 553, 138 N.E. 443 (1922).

91. C.A. Dunham Co. v. Industrial Comm'n, 16 Ill. 2d 102, 156 N.E.2d 560 (1959).

92. See notes 43-44 supra.

93. See 93 Law J. 133-134; 34 Halsbury, Laws of England 783-84 (2d ed. Hailsham) (1940). 
special exposure of some kind. In Cooper v. North-Eástern Railway, ${ }^{94}$ an engine driver, while in charge of his engine, was injured by German bombardment of Hartlepool. Compensation was denied on the ground that the fire was indiscriminate and that therefore injury resulted from exposure common to all persons in the town. For the same reason, compensation was denied to a collector in the street, ${ }^{95}$ and to a potman cleaning a door plate, ${ }^{96}$ both injured by enemy bombs in the street. A sufficient special risk was found where the workman's place of employment had a glass roof, ${ }^{97}$ and where a messenger was caught during an errand in a warehouse in which, after a bomb hit, he was suffocated by the smoke from inflammable materials stored there. ${ }^{98}$

After the date of these decisions, the English causation rule was greatly broadened until the positional-risk doctrine was firmly established. ${ }^{99}$ So far as one can base a prediction on a dictum, it is a reasonable assumption that the Cooper case would today be decided differently, in view of the following statement by Slesser, L.J. in Powell $v$. Great Western Railway:"100 "This is a case of a man being, by reason of his work, brought into a locality which was dangerous, . . . whether it became dangerous after he got into the locality, by reason of someone shooting at him, or dropping a bomb on the engine, or whatever it might be, matters nothing."

\section{Other neutral risks}

A brief review of the cases leading up to this avowed acceptance of the positional-risk doctrine will be useful both to show the pattern taken by the gradual transition to this theory (which bears a striking resemblance to the New York story), and to provide at the same time a survey of miscellaneous fact situations affected by this doctrine.

The story in England may well begin with Thom v. Sinclair, ${ }^{101}$ in which a girl was injured by the fall of a wall on adjoining premises. Lord Haldane enunciated the doctrine that any injury arose out of the employment if "it was because of the nature, conditions, obligations or incidents of the employment that the workman was brought within the

94. 32 T.L.R. 131 (1915).

95. Knyvett v. Wilkinson Bros., [1918] 87 L.J.K.B. 722.

96. Allcock v. Rogers, [1918] 118 L.T. 386 (H.L.).

97. Snaith v. Palmer's Shipbuilding Co., unreported (H.L.).

98. Bird v. Keep [1918] 2 K.B. 692 (C.A.).

99. See text accompanying notes 100-07 infra.

100. [1940] 1 All E.R. 87 (C.A.) (emphasis added). See text accompanying note 106 infra.

101. [1917] 116 L.T. 609 (H.L.). 
zone of special danger."102 In Allcock v. Rogers, ${ }^{103}$ Lord Wrenbury, refusing to apply the zone-of-special-danger test to an enemy bomb in the street, admitted that the special danger did not have to be known, but interpreted the phrase to refer to some inherent quality, such as an adjoining insecure wall, which made the place more dangerous than other places. This, then, seemed to require the existence of some kind of structure making the place of employment dangerous. This interpretation was limited to the facts of that particular case by Lord Atkin's judgment for the House of Lords in the Brooker ${ }^{104}$ case.

In Lawrence v. George Matthews, Ltd., ${ }^{105}$ a traveling man was struck by a tree which just happened to fall during a gale as he passed it on his motorcycle. Thom v. Sinclair was much discussed in all the opinions, some of the Justices evidently treating it as largely a contactwith-the-premises case. Lord Russell of Killowen, however, stressed the zone-of-danger idea, and applied it to the area just under the tree, adding that it was completely immaterial why the tree fell, if deceased's employment brought him there. Here we still have a "structure," although one that fell not through inherent unsoundness.

It remained for Powell v. Great Western Railway ${ }^{\mathbf{1 0 6}}$ to remove this last limitation and announce the positional or but-for rule in unqualified terms. In that case, a locomotive engineer was injured when a youth shot an airgun pellet at the locomotive and instead hit the engineer. Slesser, L.J., relying principally on Thom $v$. Sinclair, made the statement quoted above ${ }^{107}$ in connection with bombs, adding: "This man suffered this casualty . . . and it arose out of the employment, because he was at that place. It was by its very nature a place which was rendered dangerous by the shooting of the gun . . ." ${ }^{108}$ Goddard, L.J., put it in but-for terminology, and also ruled out any idea that the decision was based on the special temptation of shooting at locomotives, when he said: "The fireman had to be there. If he had not been there, he would never had been injured. . . . Therefore, I entirely fail to see how it can be argued that his accident did not arise out of his employ-

102. Id. at 613 .

103. [1918] 118 L.T. 386,387 (H.L.).

104. Brooker v. Borthwick and Sons, [1933] A.C. 669 . See note 34 supra.

105. [1929] 1 K.B. 1 (1928). Accord, Kaycee Coal Co. v. Short, 450 S.W.2d 262 (Ky. App. 1970). Decedent's truck was struck by a falling tree while he was traveling between two parts of the employer's premises. The death was held to be compensable as a positional risk, since decedent's exposure was the result of his work.

106. [1940] 1 All E.R. 87 (C.A.).

107. Id. See text accompanying note 100 supra.

108. Id. at 89 . 
ment, quite apart from the question of whether or not trains are an allurement to children. It seems to me that does not matter."109

Among the other locality risks that have been explicitly dealt with as such are hazards as diverse as runaway cars ${ }^{110}$ and falling kitchen cabinets, ${ }^{111}$ as well as insects and birds, ${ }^{112}$ already mentioned, and assaults by lunatics and children, and unexplained assaults and falls, which will be taken up later.

\section{Assaults of neutral origin}

The "neutral" category of assaults, associated with neither the work environment nor the claimant's personal life, comprises those assaults which are in essence equivalent to blind or irrational forces, such as attacks by lunatics, drunks, small children, and other irresponsibles; completely unexplained assaults; and assaults by mistake. A minority of jurisdictions are inclined to regard the neutral category as noncompensable, for want of affirmative proof of distinctive employment risk as the cause of the harm; but a growing majority, sometimes expressly applying the positional or but-for test, make awards for such injuries when sustained in the course of employment.

\section{Assaults by lunatics}

The positional-risk issue is presented in its purest form when some lunatic or drunk wanders in from the outside world and assaults an employee.

A number of courts have approached this type of risk by classifying it as a positional risk, comparable to the risk of random bullets or lightning, since it is an irrational force which is apt to strike blindly without discrimination between employee and nonemployee. ${ }^{113}$ It is

109. Id. at 90 .

110. In this instance, since the jurisdiction involved was consciously determined not to accept the positional-risk doctrine in any guise, the result of this classification was a denial of compensation. Lathrop v. Tobin-Hamilton Shoe Mfg. Co., 402 S.W.2d 16 (Mo. Ct. App. 1966). Claimant was struck by a driverless runaway car which came through a large window near the machine she operated. The court held that this was not a street risk case, since the accident did not contribute to an increase in the hazard relative to the general public. The accident was classified as a positional risk, and compensation was denied.

111. Brooks v. Dee Realty Co., 72 N.J. Super. 499, 178 A.2d 644 (1962).

112. See note 84 supra. See also Travelers Ins. Co. v. Williams, 378 S.W.2d 110 (Tex. Civ. App. 1964). Decedent was stung by a wasp. This resulted in a heart attack. the cause of death. Testimony was given that there were wasps on the premises, and that several workers had been stung. Compensation was awarded.

113. Federal: Hartford Accident \& Indem. Co. v. Hoage, 85 F.2d 417 (D.C. Cir. 
interesting to trace an almost complete parallel between the lunatic-assault cases and stray-bullet cases, as they originate as extensions of the street-risk doctrine, and are compelled eventually to burst open the factual boundaries imposed by that doctrine and expand into a principle of general applicability.

In Katz v. A. Kadans \& Co. ${ }^{114}$ an attack by a roving lunatic who was slashing at everyone in sight was held compensable because the claimant was, by the nature of his job as chauffeur, exposed to the "jostling crowds" of the city street, with the usual proportion of lunatics included. An indoor attack by a lunatic was certain to occur eventually somewhere, and presently such a case came before the Court of Appeals for the District of Columbia. ${ }^{115}$ The claimant, a chef, had been stabbed by a roving madman who had found his way into the restaurant kitchen. The kitchen was not entirely secluded, since the route to the washroom lay through it, but on the other hand it was a far cry from the teeming crowds of the street. In awarding compensation, the court relied at first on the locality-risk theory, when it said: "[T] he claimant's injury arose out of his employment, because the terms and conditions of his employment placed the claimant in the position wherein he was assaulted ...."116 However, for good measure, it later added that the analogy of street-risk cases applied because the kitchen was in some degree accessible to the public.

1936). See text accompanying note 115 infra.

Colorado: Iondon Guar. \& Accident Co. v. McCoy, 97 Colo. 13, 45 P.2d 900 (1935). See text accompanying note 117 infra.

Hawaii: Asaeda v. Haraguchi, 37 Hawaii 556 (1947). See text accompanying note 119 infra.

Idaho: Louie v. Bamboo Gardens, 67 Idaho 469, 185 P.2d 712 (1947). See text accompanying note 120 infra.

Kentucky: Corken v. Corken Steel Prods., Inc., 385 S.W.2d 949 (Ky. App. 1964). Decedent, a salesman, was shot by an insane stranger while returning to his car after lunch. The court, expressly approving the positional-risk test as generally applicable, stated that for compensation purposes it was sufficient that the employment caused the exposure. Compensation was awarded. Lexington Ry. System v. True, 276 Ky. 446, 124 S.W.2d 467 (Ky. App. 1939) was overruled.

Texas: Travelers Ins. Co. v. Hampton, 414 S.W.2d 712 (Tex. Civ. App. 1967). Decedent was killed as he left his place of employment with a fellow-employee. The shooting was done by a mentally ill cousin of the other employee, and was the result of a grudge held by the cousin against the other employee. Decedent merely happened to be at the scene when the incident occurred. . The court held that the sole reason for decedent's contact with the killer was the employment, and that therefore the death was compensable.

114. 232 N.Y. 420,134 N.E. 330 (1922).

115. Hartford Accident \& Indem. Co. v. Hoage, 85 F.2d 417 (D.C. Cir. 1936).

116. Id. at 418 . 
But suppose not even this could be said. Suppose the attack occurred in a private home. Would the New York or District of Columbia courts award compensation? The question will some day have to be faced, as it was by the Colorado Supreme Court in London Guarantee \& Accident Co. v. McCoy. ${ }^{117}$ There, a sales agent in the course of a business trip stopped in at a friend's home to make a necessary business phone call. At just this moment, his friend's father-in-law had one of his rare attacks of homicidal mania, and attacked not only claimant but his wife and daughters. The death was held compensable, not on any fiction or analogy of street risks, but simply on the ground that the duties of his employment had placed claimant in that place at that particular time when the assailant happened to have his onset of criminal mania. Colorado had precedent for this theory going back to its 1927 lightning case. ${ }^{118}$

The same reasoning was adopted by the Supreme Court of Hawaii in Asaeda v. Haraguchi, ${ }^{119}$ in which the locale of the lunatic's assault was the yard of a residence where the claimant, a house painter, was eating his lunch. Compensation was awarded on the ground that the employment brought claimant to the place of danger, athough it was only in retrospect that it could be seen to have been a place of danger, due to human agencies that could not have been foreseen or expected.

The Supreme Court of Idaho has also adopted this view, and may indeed have carried it a step further, by extending it to a delusion which makes the madman seek out this particular victim, rather than kill indiscriminately. In Louie v. Bamboo Gardens, ${ }^{120}$ Hong had the idea that members of a tong to which Louie belonged were seeking to kill Hong because the tong thought Hong had turned state's evidence on a narcotics charge. Hong was wrong about the tong; in fact, the whole thing was an insane obsession. But Hong came into the restaurant where Louie worked and shot three times, one shot striking Louie. The court, in reversing an award denying compensation, first said that there was no evidence that Hong was particularly looking for Louie, but added:

It may, however, be of no significance as to whether or not said Hong was looking for Tom Louie at the time he shot him and had either a real or imaginary grievance against him. The fact remains that it was an accidental injury and under the Workmen's Compensation Law,

117. 97 Colo. 13, 45 P.2d 900 (1935).

118. See Aetna Life Ins. Co. v. Industrial Comm'n, 81 Colo. 233, 254 P. 995 (1927).

119. 37 Hawaii 556 (1947).

120. 67 Idaho 469,185 P.2d 712 (1947). 
claimant and appellant is entitled to receive compensation as a result of said injury. ${ }^{121}$

The court relied heavily on the lunatic-assault cases from the District of Columbia ${ }^{122}$ and Colorado, ${ }^{123}$ and concluded:

[T] he injury was the result of a risk to which appellant was subjected in the course of his employment, and to which he would not have been subjected had he not been so employed. . . . It was his employment that placed him in the position and environment wherein he was assaulted and sustained the accidental injury. ${ }^{124}$

There are several contra cases, however, including one or two fairly recent ones. ${ }^{125}$ For example, in a Tennessee case, ${ }^{126}$ a traveling man who was waiting for his lunch in a restaurant along the way was subjected to an unexpected and unprovoked attack by a lunatic or drunk. The court denied compensation, asserting that there was no distinction between assaults made by mentally responsible and mentally irresponsible strangers, since neither had any origin in the employment. Similarly, in a plainly erroneous Maine case, ${ }^{127}$ a foreman who worked on the evening shift heard a shot and went to the gate to investigate. As he stepped into the darkness he was deliberately shot by a crazed soldier. The court first examined the question whether the foreman was technically performing his duties while investigating the disturbance, and concluded he was not, since "it was not incumbent on him" to make such investigations. The court then scrutinized the reasonableness of his conduct, saying, "it does not appear that he, entirely unarmed, could perform any useful service. . . . He went out, utterly defenseless . . ."128 and so on. Compensation was therefore denied.

121. Id. at 474,185 P.2d at 714 .

122. Hartford Accident \& Indem. Co. v. Hoage, 85 F.2d 417 (D.C. Cir. 1936).

123. London Guar. \& Accident Co. v. McCoy, 97 Colo. 13, 45 P.2d 900 (1935).

124. 67 Idaho at 483,185 P.2d at 716.

125. Illinois: Belden Hotel Co. v. Industrial Comm'n, 44 Ill. 2d 253, 255 N.E.2d 439 (1970). Decedent was shot by the insane husband of a maid employed at a rooming house in which decedent allegedly worked. Although the court also affirmed a ruling that decedent was not an employee, it further indicated that decedent's death was the result of the insane jealousy of his attacker, and did not arise out of the employment.

Maine: Hawkins v. Portland Gas Light Co., 141 Me. 288, 43 A.2d 718 (1945). See text accompanying note 127 infra.

Oklahoma: Graham v. Graham, 390 P.2d 892 (Okla. 1964). The husband of a co-worker entered the cafe and shot his wife, the claimant's husband, and a customer. The incident was attributed to the assailant's mental condition rather than any employment factors. Compensation denied.

Tennessee: Thornton v. R.C.A. Serv. Co., 188 Tenn. 644, 221 S.W.2d 954 (1949). See text accompanying note 126 infra.

126. Thornton v. R.C.A. Serv. Co., 188 Tenn. 644, 221 S.W.2d 954 (1949).

127. Hawkins v. Portland Gas Light Co., 141 Me. 288, 43 A.2d 718 (1945).

128. Id. at $293,43 \mathrm{~A} .2 \mathrm{~d}$ at 720 . 


\section{Assaults by children}

Intentional assaults by children usually take the form of throwing things, and it is probably not unfair to the children to classify their childish depredations with such other positional risks as lunatics, mad dogs, and hurricanes. In fact, the first clear enunciation of the positional-risk doctrine occurred in the English case, already mentioned, ${ }^{129}$ which awarded compensation to the locomotive fireman who was hit by a pellet aimed at the locomotive by a boy with an air gun. New York in 1926 denied compensation to an employee who was hit in the eye by a piece of wire thrown by a youthful trespasser from adjoining property; ${ }^{130}$ but this case must be read in the light of the subsequent New York cases, discussed earlier, involving other irrational forces such as falling cornices, stray bullets, and homicidal maniacs.

\section{Unexplained assaults}

Occasionally an assault occurs for which no explanation whatever appears, either because the assault was unwitnessed, or because, even with all the facts available, no one can figure out why the assault was committed. Nothing connects it with the victim privately; neither can it be shown to have had a specific employment origin. If the claimant is in fact exposed to that assault because he is discharging his duties at that time and place, there is no better reason here than in the unex-

129. Powell v. Great Western Ry., [1940] 1 All E.R. 87 (C.A.). See text accompanying notes 100, 109 supra. Accord, Challis v. London \& S.W. Ry., [1905] 2 K.B. 154 (C.A.). In the Challis case there was some reliance on the particular attractiveness of locomotives as juvenile targets, but in the Powell case this consideration was expressly disavowed as a concurrent ground for the decision. 1 All E.R. at 90 (MacKinnon, L.J., concurring). See text accompanying note 109 supra.

130. Isabelle v. J.H. Bode \& Co., 215 App. Div. 184, 213 N.Y.S. 185 (1926). But see Town of Lindsay v. Sawyer, 156 Okla. 32, 9 P.2d 30 (1932), in which a city employee who was normally engaged in hazardous employment was injured while engaged in conversation with one of the city's suppliers by the explosion of a torpedo thrown by a small boy. Recovery was allowed. See also Gregory v. Lewis Sales Co., 348 S.W.2d 743 (Mo. Ct. App. 1961). A furniture salesman suffered the indignity and subsequent injury of having a chair pulled out from under him just as he was about to sit down. The pranikster was a local newsboy who had come into the store from the street. There was no evidence that the newsboy and the salesman had previously engaged in such byplay, and in fact, the claimant based his case on assault rather than on horseplay. The court denied the claim on the ground that, while the injuries occurred during the course of employment, they did not arise out of the employment. The "assault" was totally unconnected to the duties of his employment, to any particular hazards of the employment or to any natural and reasonable incident of the employment. Compensation was denied. Note that this Missouri court is consciously and almost aggressively opposed to the positional-risk doctrine. See note 110 supra. 
plained-fall or death cases, discussed later, ${ }^{131}$ to deny an award merely because claimant cannot positively show that the assault was motivated by something connected with the work. Although the cases are more evenly divided on unexplained assaults than on unexplained falls or deaths, there is now a demonstrably larger body of authority for awarding compensation ${ }^{132}$ on these facts than for denying it. ${ }^{133}$

131. See notes 176-218 infra and accompanying text.

132. Federal: Casualty Reciprocal Exch. v. Johnson, 148 F.2d 228 (5th Cir. 1945). See text accompanying note 134 infra.

Idaho: Mayo v. Safeway Stores, Inc., 93 Idaho 161, 457 P.2d 400 (1969). Decedent, a store manager, was beaten to death by an employee who then committed suicide. No explanation was given for the attack. Because of the absence of a showing of either a personal or work-connected reason for the attack, the death was held to result from neutral causes, and the court held that under these circumstances a rebuttable presumption of compensability was presented, and since the employer did not present evidence that the death was from a personal risk, death benefits were properly awarded. Wells v. Robinson Constr., 52 Idaho 562, 16 P.2d 1059 (1932), was overruled.

Kentucky: Coomes v. Robertson Lumber Co., 427 S.W.2d 809 (Ky. App. 1968). Claimant was seen unloading lumber from a truck, and shortly thereafter was found by the truck dazed and bleeding from a head wound. There were no witnesses to the incident, and because of the consequences of the injury, claimant vas not able to explain what had happened. The court reversed a denial of compensation benefits. Contra, Stapleton v. Fork Junction Coal Co., 247 S.W.2d 372 (Ky. App. 1952), denying compensation to a night watchman who was assaulted while asleep. There was some indication that employee could have told more than he did.

Massachusetts: McLean's Case, 323 Mass. 35, 80 N.E.2d 40 (1948). See text accompanying note 135 infra.

Minnesota: See Gagne v. Oreck, 266 Minn. 1, 122 N.W.2d 589 (1963), in which the compensability of an unexplained assault on the premises depended upon whether the claimant was performing employment duties or was on a personal mission at the time.

New Mexico: Ensley v. Grace, 76 N.M. 691, 417 P.2d 885 (1966). Decedent, a bookkeeper, was shot by a co-employee, who then took his own life. The murder was unwitnessed, and there was no evidence as to its cause. Since the decedent was at work, these facts were held sufficient to raise a presumption that her death was compensable. Compensation was awarded.

New York: Valenti v. Valenti, 28 App. Div. 2d 572, 279 N.Y.S.2d 474 (1967). Decedent, a restaurant manager, was shot by a customer. There was no reason given for the killing. The court held that there was no evidence to overcome the presumption of compensability. Compensation was awarded. See Fox v. Carpenters Local 606, 33 App. Div. 2d 605, 304 N.Y.S.2d 464 (1969). Decedent, a union business agent, was assaulted and fatally beaten. There was testimony that there was ill feeling and tension within the union, and that the assailant might have been a certain individual whose motives were related to union business. Evidence held sufficient to support the conclusion that the attack was work-connected, even though the assailant was not positively identified. Award of death benefits affirmed.

North Dakota: Lippman v. North Dakota Workmen's Compensation Bureau, 79 N.D. 248, 55 N.W.2d 453 (1952). Compensation was awarded to a waitress who was shot by a customer who immediately killed himself. The motive was unknown.

Oklahoma: B \& B Nursing Home v. Blair, 496 P.2d 795 (Okla. 1972). Claimant 
In Casualty Reciprocal Exchange v. Johnson, ${ }^{134}$ the deceased was a Negro employee who was shot while on a loading platform of the employer by an unknown occupant of a car who drove onto the premises and deliberately shot him. The assailant was a complete stranger, and there was no personal motive; in short, the assault was completely unexplained. The defense suggested a connection with a race riot then in progress in a different part of town, but deceased knew nothing of this and had taken no part in it. An award of compensation was affirmed by the federal court applying Texas law.

McLean's Case ${ }^{135}$ brings the prestige of the Supreme Judicial Court of Massachusetts to the support of this view. Here a taxi driver was found viciously beaten from behind with a hammer. He had not been robbed, although he had thirty-six dollars in his wallet. There was no

was employed in a nursing home, and was attacked and beaten by an unknown assailant when she entered the laundry room at 3:00 a.m. There was no direct evidence as to the motive for the assault, and claimant was neither robbed nor sexually assaulted. Adopting the rationale here favored as to unexplained assaults, the court held that an award of benefits was proper. The court said flatly: "If the injured party is actually on the job working in the course of his employment for the employer at the time the assault occurred, he is entitled to compensation benefits, although the assailant may be unknown, and the cause of the assault is not directly related to the business of the employer." 496 P.2d at 797.

133. Colorado: Rocky Mtn. Fuel Co. v. Kruzic, 94 Colo. 398, 30 P.2d 868 (1934). But see text accompanying notes 137-38 infra.

Georgia: Francis v. Liberty Mut. Ins. Co., 95 Ga. 225, 97 S.E.2d 553 (1957), involving an unexplained shooting of an employee by a neighbor while the employee was entering the post office to get the employer's mail.

Illinois: Math Igler's Casino, Inc. v. Industrial Comm'n, 394 Ill. 330, 68 N.E.2d 773 (1946). See text accompanying note 139 infra.

Kansas: Siebert v. Hock, 199 Kan. 299, 428 P.2d 825 (1967). Decedent had been employed as general manager of a dairy, and because he worked late hours had been permitted to rest on a couch located in the office. He was found shot to death, the shooting having occurred between midnight and 2:00 a.m. Nothing was stolen, although decedent had $\$ 100 \mathrm{cash}$, and the dairy receipts were in the safe. Several days prior to his death decedent had beaten his wife, after which she had left him. His brother had become angry at him, and there was evidence that the brother was in love with decedent's wife. The shooting was done with a .22 , and decedent's .22 was missing from his car and was never found. Six months later the office safe was opened and robbed. The court held that from the facts stated it was improper to infer that decedent was killed in the course of a burglary, and therefore the death was not compensable.

Missouri: Toole v. Bechtel Corp., 291 S.W.2d 874 (Mo. 1956), involving an unexplained shooting by a co-employee at lunch time. See Kelly v. Sohio Chem. Co., 392 S.W.2d 255 (Mo. 1965). Claimant was struck on the head by an unknown assailant while at work. There was no indication why the assault was made. The court denied compensation, aff'g 383 S.W.2d 146 (Mo. Ct. App. 1964).

134. 148 F.2d 228 (5th Cir. 1945).

135. 323 Mass. 35,80 N.E.2d 40 (1948). 
explanation whatever of the assault, which might have had a private as well as an occupational origin. Compensation was awarded, on the simple ground that the "employment brought him in contact with the risk that in fact caused his injuries."136

Several cases that have arisen on similar facts have denied recovery. A Colorado case, ${ }^{137}$ while on its facts a clear denial of compensation for an unexplained assault, is of dubious value now in indicating the general causation principles in force in Colorado, in view of the avowed adoption of the positional-risk test in the case of the assault on a traveling man by a lunatic in a private home where the traveling man had gone to make a phone call. ${ }^{138}$

Another contra decision was handed down by the Supreme Court of Illinois in 1946. ${ }^{139}$ Here claimant and assailant worked in the same kitchen. Shortly after claimant's arrival at work, accompanied by cordial greetings to assailant, who was on friendly terms with the claimant, the assailant, with no word and no explanation, walked over to claimant and struck him in the eye with a ladle, blinding one eye. The assailant then walked out without comment, and never came back. The Supreme Court reversed the award given by the commission and lower court, on the ground that the claimant had not affirmatively proved that the assault grew out of a risk peculiar to the nature of the employment.

Claimant should be given the benefit of the rules applicable to unexplained assaults and deaths not only when the assault is unwitnessed but also when, though witnessed, its motive and character are inexplicable. This point was slighted in Giles v. W.E. Beverage Corp. ${ }^{140}$ In

136. Id. at 38,80 N.E.2d at 43 .

137. Rocky Mtn. Fuel Co. v. Kruzic, 94 Colo. 398, 30 P.2d $\$ 68$ (1934).

138. London Guar. \& Accident Co. v. McCoy, 97 Colo. 13, 45 P.2d 900 (1935). But cf. Miller v. Denver Post, 137 Colo. 61, 322 P.2d 661 (1958), denying compensation to a newsboy injured by a fellow-carrier in the course of a chase to retrieve a radio aerial taken from his bicycle.

139. Math Igler's Casino, Inc. v. Industrial Comm'n, 394 Ill. 330, 68 N.E.2d 773 (1946).

A subsequent Illinois case with remarkably similar facts reached the same result. American Brake Shoe Co. v. Industrial Comm'n, 20 Ill. 2d 132, 169 N.E.2d 256 (1960). A co-employee came up behind claimant, threw him to the ground fracturing his an$\mathrm{kle}$, and walked away-all without saying a word. Compensation was denied.

140. 133 N.J.L. 137, 43 A.2d 286 (1945), aff'd, 134 N.J.L. 234, 46 A.2d 728 (1946).

In Everts v. Jorgensen, 227 Iowa 818, 289 N.W. 11 (1939), compensation was awarded the viction of a witnessed but inexplicable assault; but the discussion concerned largely the effect of a statutory exclusion of injuries due to assaults for personal reasons. The employer contended that the claimant had the burden of proving that the assault was not based on personal grounds. The court rejected this contention, placing the burden of proving the assault a privately motivated one on the employer asserting the 
that case a liquor store employee was shot and killed by two men for unknown reasons. No money was stolen, and the assailants were seen but not recognized. Claimant relied in part on the presumption that when unexplained death occurs in the course of employment it arises out of the employment. The court replied that this principle was inapplicable because "here there is no lack of evidence as to how Giles suffered death."141 The Supreme Court of New Jersey evidently failed to see that the identical principle pervades both unexplained and unwitnessed assaults. Certainly, there was evidence of how death occurred, just as there is in almost every unexplained death case-by shooting, by beating, by falls down elevator shafts, and the like. The "how" is not the crucial issue; the crucial issue is the "why", and the "why" is just as obscure in a witnessed but completely inexplicable assault, fall, or death as it is in an unwitnessed one.

\section{Intentional assaults by mistake or in a melee}

Shootings by mistake or in a general melee resemble in principle the previous illustrations of irrational and unexplained assault. A good factual illustration is supplied by Harbroe's Case, ${ }^{142}$ although it is inconceivable, in the light of the subsequent development of Massachusetts compensation doctrine, ${ }^{143}$ that the case would be followed today. A night watchman was killed on duty under the following circumstances: A deputy sheriff in pursuit of burglars mistook the watchman for one of the burglars, while the watchman made the same mistake as to the deputy. In the resulting exchange of shots the watchman was killed. The decision was based on the following premise: "It cannot reasonably be said that the risk of being shot by trespassing lawbreakers is incidental to or has its origin in the nature of a night watchman's ordinary employment." ${ }^{44}$ This extraordinary view is, of course, now discredited by the virtually universal holding that the risk of such assault is an inherent part of the job of being a night watchman. ${ }^{145}$ An Illinois case that resembles Harbroe's Case both in its facts and in its reasoning is Sure

exclusion. The court began by saying that there was no doubt that the injury arose out of the employment, thus confining the controversy to the incidence of the burden of proof under the statutory exclusion.

141. 133 N.J.L. at 139,43 A.2d at 288.

142. 223 Mass. 139, 111 N.E. 709 (1916).

143. See Mclean's Case, 323 Mass. 35, 80 N.E.2d 40 (1948). Indeed, the Supreme Judicial Court of Massachusetts has said that Harbroe's Case "cannot be accepted as stating the present law of this Commonwealth." In re Baran's Case, 336 Mass. 342, 343,145 N.E.2d 726,727 (1957).

144. 223 Mass. at 141, 11 N.E. at 711.

145. See 1 A. Larson, The Law of Workmen's Compensation, $\$$ 11.11(a)-(b) (1972). 
Pure Ice Co. v. Industrial Commission. ${ }^{146}$ Here a night employee was shot by policemen who mistook him for a thief for whom they were looking, after he had disregarded their order to halt, and compensation was denied.

These early cases are out of line with the majority rule, which holds that intentional but mistaken assaults upon innocent victims in the course of their employment are deemed to arise out of the employment. $^{147}$

Illinois itself has more recently made an award, because of the special circumstances, to the victim of a mistaken shooting. In Scott $v$. Industrial Commission, ${ }^{148}$ the employer had posted officers to protect his property from sabotage by strikers, and deceased, who had been sent by his employer to an island so guarded, at a time when the employer had undertaken to protect his employees from strikers, was shot by the guards when he tried to land. Compensation was awarded.

Colorado provides another example of an award based on mistaken assault. ${ }^{149} \mathrm{~A}$ salesman was taking a demonstration car to a friend's commercial garage so as not to leave it exposed to frost during the night. The salesman had earlier been in business with this friend, and still had a key to the garage. As he was letting himself in, his friend, who had been lying in wait for burglars, mistook him for a burglar and shot him. Compensation was awarded, since the employment exposed deceased to this injury, and "the injury would not have occurred but for the employment." 150

An example of the analogous situation of shootings in a general

146. 320 Ill. 332,150 N.E. 909 (1926).

147. California: Atolia Mining Co. v. Industrial Accident Comm'n, 175 Cal. 691,167 P. 148 (1917), awarding compensation to a miner who was mistakenly shot by the employer's own mine guards without adequate investigation.

Colorado: Industrial Comm'n v. Ernest Irvine, Inc., 72 Colo. 573, 212 P. 829 (1923). See text accompanying note 149 infra.

Illinois: Scott v. Industrial Comm'n, 374 Ill. 225, 29 N.E.2d 93 (1940). See text accompanying note 148 infra.

Minnesota: Wold v. Chevrolet Motor Co., 147 Minn. 17, 179 N.W. 219 (1920), awarding compensation to an automobile salesman shot by a posse when he was mistaken for an auto thief.

Apparently contra:

Ohio: Jamison v. Industrial Comm'n, 73 Ohio App. 404, 56 N.E.2d 515 (1943), denying compensation in a mistaken shooting, is based on its special facts. A watchman had brought his wife along to stay with him during his watch, and during the watch she shot him thinking he was a prowler. The theory was that the watchman "created his own hazard" by bringing along his wife.

148. 374 I1l. 225,29 N.E.2d 93 (1940).

149. Industrial Comm'n v. Ernest Irvine, Inc., 72 Colo. 573, 212 P. 829 (1923).

150. Id. at $576,212 \mathrm{P}$. at 832 . 
melee is an Alabama case ${ }^{151}$ which presented the following facts: The deceased, while "on call" as an electrician, was standing near a payroll line when an argument developed between a company policeman and another employee named Carter. Presently Carter and his brother produced pistols, and in the ensuing shooting, while a whole roomful of men were scurrying for cover, deceased ran into Carter, who turned and intentionally shot deceased. There was no personal quarrel of any kind between deceased and Carter; Carter evidently thought that deceased was attempting to interfere with or restrain him. Compensation was denied on the theory that Carter's motivation at that instant was unconnected with anything having to do with the employment, being rather "blind, angry resentment" and therefore "purely personal in its conception and performance." There are several possible criticisms of this decision, one or two of which may be mentioned. For one thing, the court should have looked behind the blind resentment and asked what the character of the affray was that produced it; it was, of course, purely occupational, as the court conceded on the rehearing, when it admitted that the case would be different if the company policeman were the claimant. For another thing, the case could easily have been decided in claimant's favor on the simple theory that he was protecting the employer's interest by preventing harm, for which the employer would have been liable in compensation, to the company policeman, since, as the court stated, the assault may have been a "defensive measure to prevent any further interference by Harris or others with the Carters' assault upon Tarwater."

It will be observed that there is only a fine line between mistaken assaults, general melees and mixups, assaults by lunatics and drunks, unexplained assaults, and injury by random bullets. The random-bullet cases differ only in that the bullet was not deliberately aimed at the employee. But in every case the force that sends the bullet in its fatal direction is irrational, that is, it is a force that is specially concerned neither with the victim's private life nor with his employment status. Only one thing can be said with assurance: The injury would not have occurred except for the obligations of the employment; and if this test of causation is acceptable to a court for one of these types of cases, it should be equally acceptable for the rest.

\section{Assault produced by friction and strain of employment}

Up to this point, the assaults grouped together for positional-risk

151. Sloss-Sheffield Steel \& Iron Co. v. Harris, 218 Ala. 130, 117 So. 755, rehearing denied, 222 Ala. 470, 132 So. 727 (1931). 
purposes have been clearly "neutral" in the sense that they contained no component of personal animosity deliberately directed at this particular victim. When this cannot be said, some additional considerations and distinctions come into play.

At one extreme, it is well settled that, when the combatants have some kind of personal feud growing out of their private lives, such as quarrels about wives or girl friends, the fact that it erupts into an assault on the working premises during working hours does not make it compensable. ${ }^{152}$ On the other hand, an assault consciously aimed at a co-employee in a burst of personal anger is equally clearly compensable if the dispute itself was distinctly work-connected, as when a worker assaults a foreman who has reprimanded him about his work performance. ${ }^{153}$ The development relevant to the present analysis of the positional-risk doctrine occurred when Justice Rutledge, in the Hartford Accident case, ${ }^{154}$ carried the concept of work-connected assaults one

152. 1 A. LARSON, THE LAW OF WORKMEN'S COMPENSATION $\S 11.21$ (1972).

153. Id. $\$ 11.12$.

154. Hartford Accident \& Indem. Co. v. Cardillo, 112 F.2d 11 (D.C. Cir.), cert. denied, 310 U.S. 649 (1940).

Accord:

Arkansas: Townsend Paneling, Inc. v. Butler, 247 Ark. 818, 448 S.W.2d 347 (1970). A fellow employee offered to make a bet with claimant while they were working, and in response claimant told him that he was not interested and that the other employee should attend to his work. A few minutes later claimant was struck by the other employee. Affirming the general rule that to be compensable an assault must be related to the employment, the court held that an award of benefits to claimant was proper. Contra, Birchett v. Tuf-Nut Garment Mfg. Co., 205 Ark. 483, 169 S.W.2d 574 (1943), where a contra result was reached in a case involving a scuffle over a newspaper. The Birchett case was discredited in Southern Cotton Oil Div. v. Childress, 237 Ark. 909, 377 S.W.2d 167 (1964).

Georgia: Metropolitan Life Ins. Co. v. Coney, 102 Ga. App. 155, 115 S.E.2d 633 (1960). See text accompanying note 162 infra.

Louisiana: Velotta v. Liberty Mut. Ins. Co., 241 La. 814, 132 So. 2d 51 (1961) (involving facts strikingly similar to those in Hartford Accident-even to the nickname); Milton v. T.J. Moss Tie Co., 20 So. 2d 570 (La. App. 1944).

Mississippi: Mutual Implement \& Hardware Ins. Co. v. Pittman, 214 Miss. 823, 59 So. 2d 547 (1952), holding an inexplicably violent assault by a co-employee after a trivial exchange compensable.

New Jersey: Crotty v. Driver Harris Co., 49 N.J. Super. 60, 139 A.2d 126 (1958). See text accompanying note 165 infra.

New York: Bennett v. Dreier Structural Steel Co., 8 App. Div. 2d 178, 186 N.Y.S.2d 776 (1959), aff'd, 9 N.Y.2d 668, 212 N.Y.S.2d 79 (1961) (holding an assault by a co-employee on claimant, a known psychotic, after a gross insult by claimant, compensable); Katz v. Reissman Rothman Corp., 261 App. Div. 862, 24 N.Y.S.2d 807 (1941).

Oklahoma: Mullins v. Tanksleary, 376 P.2d 590 (Okla. 1962). The claimant asked Dan Chupp, "Say, Dubby, where do you want this sheetrock stacked?" Mr. Chupp thought the claimant had said "Dopey" or "Dummy" and hit him in the face. 
step further by holding that, even if the subject of the dispute is unrelated to the work, the assault is compensable if "the work of the participants brought them together and created the relations and conditions which resulted in the clash."15s A warehouse checker's helper, driven to desperation by being constantly called Shorty, finally called his superior a vile name, and was immediately knocked down, receiving the injuries for which compensation was claimed. Here there was no work dispute; ${ }^{150}$ neither was there personal enmity, in the sense that the

The court held that the spontaneous assault, unrelated to employment and unrelated to personal animosity, "lay within that range of work-connected peril which was inseparable from the risk incidental to the employment." Id. at 592.

South Dakota: Anderson v. Hotel Cataract, 70 S.D. 376, 17 N.W.2d 913 (1945). See text accompanying note 163 infra.

Wisconsin: Nash-Kelvinator Corp. v. Industrial Comm'n, 266 Wis. 81, 62 N.W.2d 567 (1954). See text accompanying note 160 infra.

155. 112 F.2d at 18.

156. The friction-and-strain doctrine enunciated by Justice Rutledge has been rejected by some courts, which continue to treat a quarrel as private unless the subject of the quarrel is related to the work. For example, in .Willis v. Taylor \& Fenn Co., 137 Conn. 626, 79 A.2d $\$ 21$ (1951), the claimant found some offensive language written in his locker, and accused a co-employee of its authorship. An argument ensued; claimant reached for something in his pocket which the co-employee thought was a knife; and the co-employee hit claimant with a rake. The Supreme Court of Errors of Connecticut in 1951 reaffirmed its 1918 statement in Jacquemin v. Turner \& Seymour Mfg. Co., 92 Conn. 382, 384, 103 A. 115, 116 (1918), that:

[i]f one employe assaults another employe solely to gratify his feeling of anger or hatred, the injury results from the voluntary act of the assailant, and cannot be said to arise either directly out of the employment or as an incident of it. But when the employe is assaulted while he is defending his employer, or his employer's property, or his employer's interests, or when the assault was incidental to some duty of his employment, the injuries he suffers in consequence of the assault will, as a rule, arise out of the employment.

The court goes on, still quoting from the earlier case, in effect to reject Justice Rutledge's view:

The fact that employes sometimes quarrel and fight while at work does not make the injury which may result one which arises out of their employment. There must be some reasonable connection between the injury suffered and the employment or the conditions under which it is pursued. 92 Conn. 382, 387, 103 A. 115, 116.

Missouri has also expressly held that it cannot take the broad Rutledge view under its statute. Thus, compensation was denied to the widow of a worker who was killed by a coemployee over an argument about stealing wine brought to the premises, in Lardge v. Concrete Prod. Mfg. Co., 251 S.W.2d 49 (Mo. 1952), and even to the innocent victim of a stray bullet fired by one co-employee at another co-employee over a quarrel about who found a five-cent piece, in Long v. Schultz Shoe Co., 257 S.W.2d 211 (Mo. Ct. App. 1953).

Several other states have also resisted the trend toward the friction-and-strain rule. See Martin v. Sloss-Sheffield Iron \& Steel Co., 216 Ala. 500, 113 So. 2d 578 (1957); Huddleston v. Industrial Comm'n, 271 Ill. 2d 446, 189 N.E.2d 353 (1963); Jones v. Schiek's Cafe, 277 Minn. 273, 152 N.W.2d 356 (1967); Fautheree v. Insulation \& Specialities, Inc., 67 N.M. 230, 354 P.2d 526 (1960); Davis v. Industrial Comm'n, 
animosity was imported by the participants from the realm of their private lives. The reason for the decision is best given in Justice Rutledge's own expressive language:

This view recognizes that work places men under strains and fatigue from human and mechanical impacts, creating frictions which explode in myriads of ways, only some of which are immediately relevant to their tasks. Personal animosities are created by working together on the assembly line or in traffic. Others initiated outside the job are magnified to the breaking point by its compelled contacts. No worker is immune to these pressures and impacts upon temperament. They accumulate and explode over incidents trivial and important, personal and official. But the explosion point is merely the culmination of the antecedent pressures. That it is not relevant to the immediate task, involves a lapse from duty, or contains an element of volition or illegality does not disconnect it from them nor nullify their causal effect in producing its injurious consequences. ${ }^{157}$

Justice Rutledge's word picture conjures up a mental image of a noisy, frantic environment, with exasperated workmen jostling and bumping as they make their hurried way between screaming lathes and slamming presses. But one wonders if an equally explosive pressure might not be built up between a receptionist and stenographer glaring day after day at each other in the carpeted stillness of a Wall Street law office. The essence of the decision, then, seems to be the enforced bringing-together, rather than any outward trappings producing nerve strain.

This view is supported by the fact that Justice Rutledge drew heavily upon positional-risk cases to support the decision. The District of Columbia Court of Appeals had already accepted the positional doctrine in cases involving an unexplained fall ${ }^{158}$ and a lunatic assault. ${ }^{159}$ $\mathrm{He}$ regarded the present case as an extension of this principle from the realm of physical forces to that of volitional human forces. Instead of being so placed by his duties as to receive the impact of a random bullet or a falling cornice, the claimant is so placed as to receive the impact of his co-worker's personality. Like the stray bullet, the topic of dispute may arrive from outside the boundaries of the employment without affecting the result.

148 N.E.2d 100 (Ohio App. 1958); Gaudette v. Glass-Kraft, Inc., 91 R.I. 304, 163 A.2d 23 (1960).

157. 112 F.2d at 17.

158. New Amsterdam Cas. Co. v. Hoage, 62 F.2d 468 (D.C. Cir. 1932). See text accompanying note 186 infra.

159. Hartford Accident \& Indem. Co. y. Hoage. 85 F.2d 417 (D.C. Cir. 1936). See text accompanying note 115 supra. 
One such topic is politics, a notorious breeder of friction and strain. In the Nash-Kelvinator case, ${ }^{100}$ the claimant, who had signed a peace petition that was allegedly Communist-inspired, was thrown out of the plant by his co-employees and seriously injured. The court squarely rested its finding of compensability on the ground that " $[w]$ here the work environment is one of the causative factors of the assault, it is immaterial whether the motive is or is not work-connected." ${ }^{161}$ Similarly in the Coney case, ${ }^{162}$ three employees riding a car during a covered trip got into an argument on segregation at the climax of which the driver, taking certain remarks as an insult to himself as a "Yankee," slammed the brakes so violently that claimant received a whiplash injury; compensation was awarded.

\section{Personal assaults}

It is not a very great step from the friction-and-strain theory to the positional-risk or but-for theory in assault cases-especially since Justice Rutledge himself invoked the positional-risk principle in his Hartford Accident opinion. Probably the first court to take this step was the Supreme Court of South Dakota. In Anderson v. Hotel Cataract, ${ }^{163}$ in which a co-employee assaulted decedent after decedent had quit work in indignation over the co-employee's taunts, the court, after quoting the Hartford Accident opinion at length, said:

But for that employment and the presence of decedent at his post of duty in the engine room the assault would not have been made . . . . Painter's opinion of deceased's capability was generated by their association in the employment, and his disparaging statements, which set forces in motion culminating in the assault, were directed at deceased as an employee. $^{104}$

The but-for rule as applied to assault has been concisely summed up by the New Jersey court as follows: "Under the 'but-for' test, assaults by co-workers are compensable as long as they are not motivated by personal vengeance stemming from contact with the employee outside of the employment." ${ }^{165}$ Using this clear rule, the court awarded

160. Nash-Kelvinator Corp. v. Industrial Comm'n, 266 Wis. 81,62 N.D.2d 567 (1954).

161. Id. at 86,62 N.W.2d at 570 .

162. Metropolitan Life Ins. Co. v. Coney, 102 Ga. App. 155, 115 S.E.2d 633 (1960); cf. Hartford Acc. \& Indemn. Co. v. Zachary, 69 Ga. App. 250, 25 S.E.2d 135 (1943), an earlier Georgia case denying compensation to a dishwasher who was struck with a cleaver by a cook because the dishwasher constantly taunted him about being a gossip.

163. 70 S.D. 376, 17 N.W.2d 913 (1945).

164. Id. at 384., 17 N.W.2d at 917 .

165. Crotty v. Driver Harris Co., 49 N.J. Super. 60, 73, 139 A.2d 126, 134 (1958). 
compensation when an employee had been robbed of his paycheck and murdered by a co-employee. ${ }^{160}$ This holding confirms the view that any jurisdiction which, like New Jersey, has adopted the positional-risk doctrine should generally have no difficulty applying it to disputes induced by compulsory human contact and so reaching the same result as that in the Hartford Acident case. ${ }^{167}$

In this category of assault cases, it is particularly important to keep constantly in mind that the motivation of the assault, as stressed in the New Jersey formulation, must not be "personal vengeance stemming from contact with the employee outside the employment."168 When it is clear that the origin of the assault was purely private and personal, and that the employment contributed nothing to the episode, whether by engendering or exacerbating the quarrel or facilitating the assault, the assault should be held noncompensable even in states fully accepting the positional-risk test, since that test applies only when the risk is "neutral." A failure to recognize this limitation on the positional-risk test led to an erroneous decision, later corrected, by Mississippi, and to some similar erroneous decisions, still uncorrected, by Louisiana. Mississippi's original opinion in the Brookhaven case $\mathrm{e}^{160}$ (later withdrawn) awarded compensation to a laundry-route driver shot by a customer with whose wife decedent had been carrying on an affair during

The but-for theory had been earlier applied to an assault on a truck driver by an outsider. Sanders v. Jarka Corp., 1 N.J. 36, 61 A.2d 641 (1948).

However, in Lester v. Elliott Bros. Trucking Co., 18 N.J. 434, 114 A.2d 8 (1955), a quarrel between co-employees over punching a time clock, resulting in an assault, was not held sufficiently work-connected to satisfy the Sanders case rule, by a vote of 4-to-3.

166. Crotty v. Driver Harris Co., 49 N.J. Super. 60, 139 A.2d 126 (1958).

However, when the claimant, standing on a ladder, made disparaging remarks to an acquaintance, and was assaulted, his contention that the positional-risk doctrine applied because he was "trapped" on the ladder was rejected. Pittel v. Rubin Bros. Bergen Inc., 59 N.J. Super. 531, 158 A.2d 210 (1960).

The New Jersey postitional-risk approach was strongly and authoritatively reaffirmed in Martin v. J. Lichtman \& Sons, 42 N.J. 81, 199 A.2d 241 (1964). Claimant asked a co-worker about having two jobs. Without reply and after some delay, the coworker assaulted his interrogator. The court stated that the "but for" or "positionalrisk" analogy sufficed to define the assault as work-connected. The worker had no contacts outside their employment.

167. Cf. W.T. Edwards Hosp. v. Rakestraw, 114 So. 2d 802 (Fla. App. 1959), in which the court preferred not to apply the positional-risk when other grounds were available. Compensation was awarded for injuries occurring in a fight between coemployees over matters unrelated to the work, the court stressing that the fight took place during working hours, on the work premises, and between co-employees.

168. 49 N.J. Super. $60,73,139$ A.2d 126, 134.

169. Brookhaven Steam Laundry v. Watts, 55 So. 2d 381 (Miss. 1951), rev'd 214 Miss. 569, 59 So. 2d 294 (1952). 
his regular calls for dry cleaning. The original opinion and the dissent in the substituted opinion denying compensation ${ }^{170}$ held that it was sufficient if the employment brought decedent to the place where he was injured for personal reasons. This overlooks the justification of the positional-risk doctrine, which is that this very slight employment contribution (bringing decedent to the place where he was killed) is enough to swing the balance only if it is not offset by a positive showing of personal cause of the harm. In the usual positional cases, such as lightning, stray bullets, and lunatics running amuck, the source of the harm has no more to do with claimant's private life than with the employment. Moreover, it is difficult to say that the "position" was a source of risk at all, if the circumstances of the private quarrel were such that the assault would have been made regardless of the factor of position, since the assailant was evidently determined to have his vengeance wherever he might find his victim.

The Louisiana story begins with a case that was very close on the facts, but in which it could still be said that the employment role was not entirely neutral. Lovelady was on his way to seek a reconciliation with his wife when he saw Livingston, the very man who had alienated his wife's affections, and he took the opportunity to kill Livingston. The court, citing the fact that Livingston was working on a Sunday and that Lovelady had not intended to seek him out, held that the presence of Livingston on the highway was what caused him to be killed and awarded compensation on the positional-risk theory. ${ }^{171}$

Some element of employment contribution could be detected also in the next Louisiana case in this sequence, Williams $v$. United States Casualty Co. ${ }^{172}$ Bertha Mae Williams was employed at Lawson's saloon, where she became acquainted with Warren Mills, who operated a card game in the back room on a profit-sharing basis with Lawson. She later became Mills' common-law wife. They moved to California, but she returned alone. Mills also returned, but Bertha escaped his wrath for one night. The next night Mills came into the saloon, where Bertha had returned to work as a barmaid, and shot her in the back five times. It was stipulated that the assault was motivated by purely personal reasons. The court affirmed the compensation award on the rationale of Harvey v, Caddo De Soto Cotton Oil Co., ${ }^{173}$ in which the

170. Brookhaven Steam Laundry v. Watts, 214 Miss. 569, 640, 59 So.2d 294, 302 (1952).

171. Livingston v. Henry \& Hall, 59 So. 2d 892 (La. App. 1952).

172. 145 So. 2d 592 (La. App. 1962).

173. See note 32 supra and accompanying text. 
employee was killed by a tornado. The court noted that she was exposed to a greater hazard when she jad to leave the relative protection of the bar to serve a customer out front-where Mills shot her.

The case that appears to put Louisiana completely in a class by itself by applying the positional-risk test to a privately-motivated assault is Rogers v. Aetna Casualty \& Surety Co. ${ }^{174}$ Decedent was shot while at work as the result of a personal quarrel. The court applied the "butfor" or "positional" test and awarded compensation. The court mentioned in passing that the increased-risk test might have been applicable, since the parties were co-employees. Unfortunately the court, in a detailed opinion, never quite faced up to the precise question involved: Should the positional-risk theory be applied not only to neutral risks but also to purely personal risks? The Williams and Livingston cases had elements of special exposure to the assault, in the one case by claimant's being required to work in a barroom and in the cther by his being placed in 'the assailant's path through having to work on a road construction site. The court here would have done better to leave itself some leeway for the future in this class of cases, by utilizing the circumstance that the assailant was a co-employee. This would have avoided leaving matters in such a posture that absolutely any personal assault under any circumstances becomes compensable if it occurs within the time and space limits of the employment.

But apparently this extreme result is just what Louisiana intended, since a later case, Gorings v. Edwards, ${ }^{175}$ awarded compensation in this exact situation. Claimant was assaulted on his employer's premises while walking to work. His assailant was the husband of a woman with whom claimant had been carrying on an affair. Compensation was awarded, the arising-out test being met by a mere showing that claimant was about his employer's business and not merely pursuing his own business or pleasure at the time of the assault, and that the necessities of the employer's business reasonably required that claimant be at the place of the assault at the time that it occurred.

\section{Unexplained falls}

In the opening analysis of the three categories of risk, it was shown that a particular source of injury may be classified as "neutral" for either of two reasons: The nature of the risk may be known, but may be associated neither with the employment nor the employee personally; or the nature of the cause of harm may be simply unknown.

174. 173 So. 2d 231 (La. App. 1965).

175. 222 So. 2d 530 (La. App. 1969). 
The most common example of the latter is the unexplained fall in the course of employment. If an employee falls while walking down the sidewalk or across a level factory floor for no discoverable reason, the injury resembles that from stray bullets and other positional risks in this respect: The particular injury would not have happened if the employee had not been engaged upon an employment errand at the time. In a pure unexplained-fall case, there is no way in which an award can be justified as a matter of causation theory except by a recognition that this but-for reasoning satisfies the "arising" requirement. In appraising the extent to which courts are willing to accept this general but-for theory, then, it is significant to note that most courts confronted with the unexplained-fall problem have seen fit to award compensation. ${ }^{176}$

176. Federal: New Amsterdam Cas. Co. v. Hoage, 62 F.2d 468 (D.C. Cir. 1932). See text accompanying note 186 infra.

Connecticut: Ryerson v. A.E. Bounty Co., 107 Conn. 370, 140 A. 728 (1928). See text accompanying note 185 infra. Accord, Stankewicz v. Stanley Works, 139 Conn. 215, 92 A.2d 736 (1952).

Florida: Damon v. Central Hotel, 135 So. 2d 204 (Fla. 1961). See text accompanying note 207 infra.

Georgia: American Mut. Liab. Ins. Co. v. King, 88 Ga. App. 176, 76 S.E.2d 81 (1953), holding it immaterial whether a stroke occurred before or after a fall if the fall aggravated the condition.

Indiana: Burroughs Adding Mach. Co. v. Dehn, 110 Ind. App. 483, 39 N.E.2d 499 (1942). See text accompanying note 187 infra; Burton-Shields Co. v. Steele, 119 Ind. App. 216, 83 N.E.2d 623 (1949). See text accompanying note 189 infra.

Kentucky: Coomes v. Robertson Lumber Co., 4:7 S.W.2d 809 (Ky. App. 1968). Claimant was seen unloading lumber from a truck, and shortly thereafter was found by the truck dazed and bleeding from a head wound. ihere were no witnesses to the incident, and because of the consequences of the injury, claimant was not able to explain what had happened. The court reversed a denial of compensation benefits.

New Jersey: Spindler v. Universal Chain Corp., 11 N.J. 34, 93 A.2d 171 (1952), awarding compensation to a 75-year-old woman who inexplicably fell as she turned to replace a wrench on a shelf.

New York: Martin v. Plaut, 293 N.Y. 617, 59 N.E.2d 429 (1944) (see text accompanying note 185 infra); Unger v. New York Sportswear Co., 268 N.Y. 651, 198 N.E. 540 (1935) (see text accompanying note 184 infra); Andrews v. L. \& S. Amusement Corp., 253 N.Y. 97, 170 N.E. 506 (1930) (see text accompanying note 180 infra); Heck v. Hilton Hotels Corp., 12 App. Div. 2d 672, 207 N.Y.S.2d 693 (1960); Moraes v. Davis, 2 App. Div. 2d 619, 152 N.Y.S.2d 108 (1956); Hoye v. City of New York, 268 App. Div. 944, 51 N.Y.S.2d 613 (1944); Schiff v. Bow-Made Coat Co., 264 App. Div. 966, 37 N.Y.S.2d 58 (1942); Motto v. Chesapeake House, 252 App. Div. 906, 299 N.Y.S. 658 (1937); Bauer v. City of New York, 252 App. Div. 802, 298 N.Y.S. 853 (1937); Kefford v. Federal Reserve Bank, 246 App. Div. 660, 283 N.Y.S. 263 (1935).

See Cornaglia v. Felice Corp., 31 App. Div. 2d 688, 295 N.Y.S.2d 879 (1968). Claimant in the rcstaurant where he was employed, went downstairs, and ten minutes later returned upstairs covered with blood and unable to recall what had happened. Fellow employees found a pool of blood on the landing at the bottom of the stairs. Claimant later drove home, where his wife found him in the garage covered with blood and bleeding from the ears. He was found to have a skull fracture and concussion. Evi- 
A substantial minority, however, deny compensation in unexplained fall situations. ${ }^{177}$

dence held sufficient to support a finding that claimant was injured when he fell down the stairs at work.

North Carolina: Robbins v. Bossong Hosiery Mills, 220 N.C. 246, 17 S.E.2d 20 (1941).

Taylor v. Twin City Club, 260 N.C. 435, 132 S.E.2d 865 (1963). The employee bled to death from a scalp wound received in an unwitnessed fall. Compensation was awarded.

Calhoun v. Kimbrell's, Inc., 6 N.C. App. 386, 170 S.E.2d 177 (1969). Decedent was found lying at the bottom of some stairs where he had been working, with a skull fracture from which he eventually died. There was no explanation as to how or why he was injured. A finding that decedent had fallen down the stairs was held not supported by the evidence, but the evidence was held sufficient to support an award on the grounds that decedent had in some way fallen, causing the skull fracture and death.

England: Upton v. Great Central Ry., [1924] A.C. 302. See text accompanying note 178 infra.

177. Colorado: Finn v. Industrial Comm'n, 165 Colo. 106, 437 P.2d 542 (1968). Claimant was found lying unconscious at the place of his employment shortly after beginning work. He had a small skull fracture, head abrasions, black eyes, and bruises on his forearms. There was no explanation as to how the injuries occurred. The court stated that the circumstances surrounding the injuries did not raise a presumption of compensability, and that the claimant had failed to show that the injuries were connected with the employment. Denial of compensation affirmed.

Missouri: Wheaton v. Reiser Co., 419 S.W.2d 497 (Mo. Ct. App. 1967). Decedent was removing varnish from some pillars using a liquid varnish remover. He was seen to fall against the pillar, and then to the floor, striking his head. However, the witness who observed the fall stated that he did not trip, stumble, or slip, but merely fell over. Death was probably due to a subdural hemorrhage, which a doctor testified was a result of decedent's striking his head on the floor. There was no direct evidence as to the cause of the fall, although decedent did have a history of heart trouble. The court held that, although the commission was wrong in treating the fall as idiopathic, instead of as the result of unknown causes, it was correct in denying death benefits, since claimant had failed to show a causal connection between the work and the fall, and there was no presumption applicable to the circumstances of the incident.

Ohio: Postel v. Industrial Comm'n, 163 Ohio St. 617, 128 N.E.2d 29 (1955); Eggers v. Industrial Comm'n, 157 Ohio St. 70, 104 N.E.2d 681 (1952).

Oregon: Puckett v. Wagner, 487 P.2d 897 (Ore. App. 1971). Claimant was sent home from work because he had been drinking. He was found on the employer's premises lying on a sidewalk. The next day he was found to have sustained a fractured vertebra. The claimant could not recall how or why he fell, and in fact the fall might have been due to an old injury. The court held that as a matter of law the claimant had not sustained his burden of proving a compensable accident, and an award of benefits was improper.

Rhode 1sland: Grassel v. Garde Mfg. Co., 90 R.I. 1, 153 A.2d 527 (1959) (Roberts \& Paolino, JJ., dissenting).

South Carolina: Bagwell v. Ernest Burwell, Inc., 227 S.C. 444, 88 S.E.2d 611 (1955).

Wisconsin: Nielsen v. Industrial Comm'n, 14 Wis. 2d 112, 109 N.W.2d 483 (1961). See text accompanying note 209 infra.

Brickson v. Department of Indus., 40 Wis. 2d 694, 162 N.W.2d 600 (1968). 
The leading unexplained fall case, both because it was the earliest, and because it is a carefully considered pronouncement by England's highest court on the meaning of the act from which almost all American acts were copied, is Upton v. Great Central Railway, ${ }^{178}$ in which compensation was awarded to an employee who fell on a railway platform in the course of a business errand. The opinion emphasizes that the platform was not slippery or defective in any way; the cause of the fall was completely unknown. The decision of the House of Lords was unanimous. Lord Atkinson's language is of interest:

Here the accident was caused by the performance of an act the deceased was employed to perform-namely, to traverse the platform. ... Having been done in the course of the employment of the deceased, and the accident having been caused by the doing of it even incautiously, it must, I think, be held that the accident arose out of the employment of the deceased. ${ }^{179}$

The Upton case was expressly approved by the New York Court of Appeals, in these words: "An award was sustained. It would be sustained by us. We have such cases frequently." 180 It is true that New York has repeatedly sustained unexplained-fall awards. ${ }^{181}$ For example, in Martin v. Plaut, ${ }^{182}$ an award was affirmed virtually without discussion of the "arising" question on the following simple account of the accident:

Claimant, employed as a cook, was injured when she fell as she turned suddenly to pick up some of her clothes while dressing one morning in a bedroom furnished in her employer's home for her use. What caused her to fall she could not say unless it was the quickness of her movement. She had just left her bed and was dressing to go out and do her work. She was not conscious of having tripped over anything. ${ }^{183}$

Again, in Unger v. New York Sportwear Co. ${ }^{184}$ claimant testified that she did not slip or stumble, but merely "lost her balance" and fell while working along Seventh Avenue in the course of her employment. An award was affirmed.

Claimant ate lunch in the company lunch room and then went to the washroom. While leaving, she slipped and fell, and was injured. There was apparently no explanation for the fall, and, because of the absence of any credible evidence showing the cause of the fall and a relationship to the employment, a denial of benefits was held proper.

178. [1924] A.C. 302.

179. Id. at 315 .

180. Andrews v. L. \& S. Amusement Corp., 253 N.Y. 97, 101, 170 N.E.2d 506, 508 (1930).

181. See note 176 supra.

182. 293 N.Y. 617,59 N.E.2d 429 (19044).

183. Id. at 618,59 N.E.2d at 429.

184. 268 N.Y. 651,198 N.E. 540 (1935). 
Very similar to Martin v. Plaut is a Connecticut case ${ }^{185}$ in which compensation was awarded to a seventy-two-year-old man who, while preparing horse feed in his room, slipped and broke his hip when he was about to sit down in a rocking chair and tie his shoelace. And several jurisdictions have made awards on facts closely resembling those in the Unger case. In awarding compensation to a solicitor for an unexplained fall while he was crossing the street, the Court of Appeals for the District of Columbia said simply that the requirements of the employment placed him in the position where the accident occurred. ${ }^{188}$ The clearest but-for or positional language occurs in the Indiana case of Burroughs Adding Machine Co. v. Dehn. ${ }^{187}$ Here too, the facts showed merely that a city salesman, for no apparent reason, fell on a sidewalk. After speculating about all the things that might have caused the fall, including overexertion, vertigo, assault, and so on, the court decided the case squarely as an unexplained-fall problem, saying:

[T] he causal connection is sufficiently established by the fact that the Industrial Board could reasonably have determined that the accident would not have occurred and the injury would not have been received if the employee had not been required, in performing the duties of his employment, to be traveling the particular street at the particular time, under the particular conditions and environment. ${ }^{1 s s}$

This position is affirmed in a later case ${ }^{180}$ in which the court said: "The cause of the fall may be disregarded if the fall resulted in the injuries which would not have occurred except for the employment."130

In another case involving a completely inexplicable fall, ${ }^{101}$ the North Carolina Supreme Court in effect said that when an accident occurred in the course of employment, and there is no affirmative evidence that it arose from a cause independent of the employment, an award would be sustained. In the terminology adopted by this article, this would mean that all injuries from neutral risks are compensable.

There are several cases in which the contrary result has been reached, but to a considerable degree this appears to be the result of

185. Ryerson v. A.E. Bounty Co., 107 Conn. 370, 140 A. 728 (1928).

186. New Amsterdam Cas. Co. v. Hoage, 62 F.2d 468 (D.C. Cir. 1932).

187. 110 Ind. App. 483, 39 N.E.2d 499 (1942).

188. Id. at 503,39 N.E. $2 \mathrm{~d}$ at 507.

189. Burton-Shields Co. v. Steele, 119 Ind. App. 216, 83 N.E.2d 623 (1949).

But cf. the later history of the positional-risk doctrine in Indiana discussed in the text accompanying notes 29-31 supra.

190. 119 Ind. App. at 222, 83 N.E.2d at 625.

191. Robins v. Bossong Hosiery Mills, 220 N.C. 246, 17 S.E.2d 20 (1941). 
some confusion between true unexplained-fall cases and cases in which there was at least some possibility of a personal or idiopathic factor contributing to the fall. Thus, in Rozek's Case ${ }^{192}$ the court said:

So far, however, as there was any evidence of the cause of the fall it tended to show that the fall and the resulting fracture of the skull were caused by heart disease. Unless this was the cause of the fall it remains wholly unexplained by evidence or reasonable inference ....

The court then went on to state in general terms that:

A fall by an employee while at work, where neither the cause of the fall nor of the resulting injury bears any special relation to his work or to the conditions under which it was performed, though it arises "in the course of" the employment, does not arise "out of" the employment within the meaning of the statute. ${ }^{193}$

This generalization seems to be at least partially in the nature of dictum, because of the presence of a personal risk-heart disease-as an explanation of the fall, supported by at least some evidence. Whenever personal disease or weakness contributes to the fall, an entirely new set of rules comes into play, since the risk is no longer neutral but either personal, or perhaps "mixed," and the majority rule requires that the employment, to offset this primarily personal causation, contribute something to the risk, such as a height from which the employee falls, or a dangerous object that he encounters. ${ }^{194}$ There are also many cases in which the fall itself is unexplained, but the employment similarly makes a contribution to the ultimate injury by having placed claimant on a height, or by putting in his way some object which he strikes in falling. Since such a contribution makes a fall compensable even when the original cause of the fall is epilepsy, vertigo, or some other clearly personal weakness, a fortiori the effects of the fall are compensable when the cause is unknown. Thus, when a workman fell backward for some reason, while lowering a flag, compensation was awarded because his head struck a cement platform on which he was standing. ${ }^{195}$ In a Massachusetts case, ${ }^{196}$ work connection was found in some evidence of slipping, and in contact with a truck that the employee struck in falling. Rozek's Case, quoted above, was distinguished on these facts. And in

192. 294 Mass. 205, 200 N.E. 903 (1936).

As to falls resulting in death, this case has been overruled by a 1971 amendment creating a presumption of coverage. See Mass. Workmen's Compensation Law $\$ 7 \mathrm{~A}$, Mass. ANn. Laws ch. 152, \$ 7A (Supp. 1972).

193. 294 Mass. at $207-08,200$ N.E. at 904-05.

194. See 1 A. Larson, The LaW of Workmen's Compensation, $\$ 12.10-14$ (1972).

195. De Vine v. Dave Steel Co., 227 N.C. 684, 44 S.E.2d 77 (1947).

196. Caccamo's Case, 316 Mass. 358, 55 N.E.2d 614 (1944). 
New York, sufficient causal relationship in unexplained-fall situations has been found when the fall was from a height because claimant's employment placed him on a wagon, ${ }^{197}$ and when the claimant in falling struck a propeller lying on a pier. ${ }^{198}$

The danger of confusion when the element of possible idiopathic causation is speculated on but is not supported by the evidence is illustrated by an intermediate New Jersey decision, Stulb v. Foodcraft, Inc. ${ }^{199}$ In this case the claimant, while standing at a desk, suddenly fell backward and fractured his skull on the concrete floor. There was no evidence on why he fell. The defense contended that the cause of the fall must have been idiopathic. The court stated that the burden of proving this fact was on the respondent, citing the Spindler ${ }^{200}$ case. But, unlike the Spindler case, decided by the Supreme Court of New Jersey, which held an unexplained fall compensable when idiopathic origin was not proved, the intermediate court abruptly concluded that, when no idiopathic cause is shown, and when the "cause is simply unknown," the case is not compensable. In the Spindler case, the court, by a process of elimination, concluded that the fall "was brought about by the employee's turning to replace the instrument she was using, to the shelf located behind her, in furtherance of the purpose of her employment. If the turn had not been endeavored the loss of balance preceding it and the fall would not have occurred."201 It is difficult to see how this can mean anything other than that unexplained falls have been held to be compensable in New Jersey by its highest court. It makes no sense to say that the cause was not unexplained because the cause was the turning to replace the tool. Reference to this fact does not "explain"; it merely tells us what the claimant was doing when the unexplained fall took place. The real question is what caused the plaintiff to fall as she was turning around. This remains completely unexplained.

It is difficult to believe that the Stulb decision will survive in New Jersey, which has extended the positional-risk doctrine not only to stray arrows ${ }^{202}$ but.even to kitchen cabinets, ${ }^{203}$ and which has, in the Spindler case, adopted the only rule that is consistent with the positional-risk

197. Mausert v. Albany Builders' Supply Co., 250 N.Y. 21, 164 N.E. 729 (1928).

198. Aanonsen v. Jakobson \& Peterson, 260 App. Div. 967, 23 N.Y.S.2d 482 (1940).

199. 76 N.J. Super. 384, 184 A.2d 673 (1962).

200. Spindler v. Universal Chain Corp., 11 N.J. 34, 93 A.2d 171 (1952).

201. Id. at 39, 93 A.2d at 173.

202. Gargiulo v. Gargiulo, 13 N.J. 8, 97 A.2d 593 (1953). See text accompanying note 1 supra.

203. Brooks v. Dee Realty Co., 72 N.J. Super. 499, 178 A.2d 644 (1962). 
doctrine: the rule that an unexplained fall, being attributable neither to the employment nor to the claimant personally, is a neutral risk. It is no answer to this to say that the burden is on the claimant to prove his case. He has proved his case when he proves an injury by accident in the course of employment from a neutral risk-as much so when the neutral risk is an unexplained event as when it is an arrow out of nowhere.

An intermediate Florida court has also had difficulty in this area because of failure to distinguish idiopathic from neutral causes of falls. In Vander Linden v. Reed Construction Corp., ${ }^{204}$ a workman, while working in a bent position with his head down for an indefinite period of time placing mortar underneath a form for piling, straightened himself up when summoned by a co-employee. As he stood up he fell to the ground and sustained injuries. There was no medical evidence indicating that the fall was due to a preexisting malady. Nevertheless, the court denied compensation, citing two idiopathic-fall cases, one involving a heart attack, ${ }^{205}$ and one involving a dizzy spell. ${ }^{206}$ The court then merely announced that there was no connection with the employment in the instant case. However, the Supreme Court of Florida, in a more recent decision, ${ }^{207}$ for all practical purposes adopted the doctrine that unexplained falls are compensable. In this case the manager of a hotel fell in the hallway of the hotel, but could not explain why. She stated: "Whether I caught my robe or whether the carpet was loose or whether I tripped on that or not, I don't know."208 The court said that the cause of the fall was not altogether unexplained, since the claimant had listed several possibilities, and that any of them would have rendered the accident compensable and would exclude any inference that the fall was idopathic. Perhaps one could justify this interpretation of the claimant's testimony on a highly legalistic and literal basis, but the obvious reading of the claimant's statement is that she simply did not know what happened at all, and was merely tossing out random examples of speculative possibilities which came to her mind.

Another decision that appears to have missed the essence of the unexplained-fall problem is Nielsen $v$. Industrial Commission. ${ }^{209}$ In this case a chambermaid fell while returning to the hotel from the hotel laundry where she had eaten lunch. She could not explain how or

204. 115 So. 2d 706 (Fla. App. 1959).

205. Protectu Awning Shutter Co. v. Cline, 154 Fla. 30, 16 So. 2d 342 (1944).

206. Foxworth v. Florida Indus. Comm'n, 86 So. 2d 147 (Fla. 1955).

207. Damon v. Central Hotel, 135 So. $2 d 204$ (Fla. 1961).

208. Id. at 205.

209. 14 Wis. $2 d 112,109$ N.W.2d 483 (1961). 
why she fell. Compensation was denied. The decision is all the more unfortunate because the court had earlier adopted the positional-risk test by stating that an injury is compensable when "[the] circumstances of the employment [place] the employee in the particular place at the particular time when he is injured by a force which is not solely personal to him."210 If the court had merely applied this test, it could have gone on to point out that an unexplained cause is a neutral cause and, when the cause is neutral, it cannot be said that the cause is "solely personal." 11 Instead, the court stated that the issue was whether there was a presumption that unexplained falls arose out of the employment. To cast the issue in terms of a presumption is merely to introduce an unnecessary fiction into the question of work connection. Work connection is shown by the fact that the injury occurred in the course of employment, and that the employment brought the employee to the place where he was injured at the time when he was injured; as against this, there is no evidence whatever of any personal contribution to the injury. This being so, there is no need to look for implied presumptions as a precondition to compensability.

In addition to these cases, there are several that deny compensation on the straightforward ground that the employee cannot recover unless he affirmatively proves his entire case, including the employment-connected nature of the cause of his fall. ${ }^{212}$ Since the compensability of unexplained falls is related to the compensability of neutral and positional risks, it is not surprising that some states that are not yet ready to accept the positional-risk doctrine are also unwilling to award compensation for unexplained falls. But, as in those jurisdictions whose decisions have been analyzed here at length, where the neutralrisk concept has been accepted for other purposes, a lot of confusion, circumlocutions, and fictions could be avoided in the unexplained-fall cases by merely accepting the proposition that what is unexplained is neutral.

\section{Unexplained deaths}

When an employee is found dead under circumstances indicating

210. Cutler-Hammer, Inc. v. Industrial Comm'n, 5 Wis. 2d 247, 253, 92 N.W.2d 824, 827 (1958).

211. The same observation can be made as to Colorado, which pioneered in applying the positional-risk test in a lightning case, Aetna Life Ins. Co. v. Industrial Comm'n, 81 Colo. 233, 254 P. 995 (1927), and a lunatic-assault case, London Guar. \& Accident Co. v. McCoy, 97 Colo. 13, 45 P.2d 900 (1935), but which has not made the carry-over of the neutral-risk principle to the unexplained-fall area. See Finn v. Industrial Comm'n, 165 Colo. 106, 437 P.2d 542 (1968).

212. See note 177 supra. 
that death took place within the time and space limits of the employment, in the absence of any evidence of what caused the death, most courts will indulge a presumption or inference that the death arose out of the employment. ${ }^{213}$ Awards for unexplained deaths can be theoretically assimilated to awards for unexplained falls and assaults by bringing them within the basic positional-risk justification: The occurrence of the death within the course of employment at least indicates that the employment brought deceased within the range of the harm, and the cause of harm, being unknown, is neutral and not personal. However, the fact that a jurisdiction makes an award in an unexplained-death case, as almost all do, is seldom in itself a reliable indication that the jurisdiction has adopted the positional-risk doctrine, and therefore this prolific category will not be discussed in detail here. The reason for this unreliability is that there are usually grounds other than positionalrisk theory on which an unexplained-death award can be rested. The commonest is the practical argument that, when the death itself has removed the only possible witness who could prove causal connection, fairness to the dependents suggests some softening of the rule requiring claimant to provide affirmative proof of each requisite element of compensability. In a number of jurisdictions this principle is expressed in a statutory presumption of compensability in unexplained-death cases. ${ }^{214}$

Moreover, the "purity" of these cases for purposes of positionalrisk theory is usually muddied either by factors suggesting some employment contribution, as when a distinctive employment hazard like a cave-in $^{215}$ or dynamite explosion ${ }^{216}$ figures in an unwitnessed death, or, conversely, by personal causal elements, as when an idiopathic weakness or disease, such as a pre-existing heart condition, ${ }^{217}$ plays a

213. See, e.g., the following cases that are relatively "pure" unexplained-death cases, in that there is nothing in the evidence suggesting even a slight inference of either an employment or a personal origin of the harm, as when the only known facts are that a night watchman is found dead at his post of duty:

Federal: Travelers Ins. Co. v. Cardillo, 140 F.2d 10 (D.C. Cir. 1943).

California: Western Grain \& Sugar Prod. Co. v. Pillsbury, 173 Cal. 135, 159 P. 423 (1916). (1917).

Illinois: Mechanics' Furniture Co. v. Industrial Bd., 281 Ill. 530, 117 N.E. 986

New Jersey: Cole v. I. Lewis Cigar Mfg. Co., 63 A.2d 293 (N.J. County Ct. 1948). 214. See Massachusetts Workmen's Compensation Law, Mass. GeN. LAws ANN. ch. 152 , § 7A (1965).

215. Macko v. Herbert Hinchman \& Son, 24 N.J. Super. 304, 94 A.2d 690 (1953), expressly disapproving the contra case of Nardone v. Public Serv. Elec. \& Gas Co., 113 N.J.L. 540, 174 A. 745 (1934).

216. Medina v. New Mexico Consol. Mining Co., 51 N.M. 493, 188 P.2d 343 (1947).

217. Fishman v. Lousan Gen. Conștr. Corp., 11 A.D.2d 887, 202 N.Y.S.2d 795 
part. Accordingly, although the normal rule in unexplained-death cases fits logically within positional-risk doctrine, it is a rarity to find this doctrine advanced as the principal justification of the result. ${ }^{21 s}$

\section{Rescue of strangers}

There remains to be noted one final category in which the positional-risk principle has figured-that of rescue of strangers. The cases in this category differ from almost all of those so far discussed in that the neutral "risk," instead of being some outside force that acts directly on claimant, is not a force but an opportunity or implied invitation to rescue, encountered by claimant because of his employment. It is not injurious by its own unaided operation, but becomes injurious only through the volitional act of the claimant in responding to the opportunity. Moreover, while in the usual positional-risk case the course of employment factor is beyond dispute, in the rescue cases the employee typically leaves the duties and premises of his employment in order to attempt the rescue.

The positional-risk element appears only when the person rescued is someone to whom the employer has no relationship or potential liability. It has long been settled that efforts to rescue co-employees, ${ }^{210}$ or other persons to whom the employer might have some duty, ${ }^{20}$ arise out of and in the course of employment. The really controversial issue in the rescue field is the question whether injury incurred in the rescue of a stranger should be held compensable.

A long step toward coverage of such injuries was taken in the lead-

(1960), aff'd, 10 N.Y.2d 919, 179 N.E.2d 712, 223 N.Y.S.2d 872 (1961), in which, even under the New York statutory presumption of coverage, compensation was denied when a carpenter died of an artery disease and myocardial infarction, having fallen from a board platform while painting a ceiling, because of the absence of any evidence of accidental injury or unusual exertion to hasten the death.

218. For further discussion of the various issues surrounding unexplained deaths, see 1 A. Larson, The LaW OF WorkMEN's CoMpensation, $\$ \$ 10.32-33$ (c) (1972).

219. Yates v. South Kirby, Featherstone \& Hemsworth Collieries [1910] 2 K.B. 538; Dragovich v. Iroquois Iron Co., 269 IIl. 478, 109 N.E. 999 (1915).

220. Thus, when a hotel cook, on discovering a fire, rushed upstairs to warn the guests, she was plainly discharging a duty owed by the innkeeper to his guests. Stilson v. Littlewood, 244 App. Div. 858, 279 N.Y.S. 781 (1935).

A similar principle, on much less impressive facts, was at work in a British case, in which a baker, employed on a ship, heard a passenger using bad language in the presence of some lady passengers, and when he ordered the villain to desist, got cut up for his pains. Compensation was awarded under the emergency doctrine, since claimant was discharging his employer's duty of protecting his passengers from the sound of profanity. Culpeck v. Orient Steam Nav. Co., 15 Butterworth's W.C.C. 187 (C.A. 1922). 
ing case of Waters $v$. William J. Taylor Co. ${ }^{221}$ The deceased was employed by one contractor on a construction project, and about twenty feet from him the employee of another contractor was trapped by a cave-in while at work on the excavation for the same building. In attempting to rescue him deceased was killed by a second cave-in, and a compensation award against the deceased's own employer was upheld by the highest New York court, the Court of Appeals.

The next leading case was Puttkammer v. Industrial Commision, ${ }^{222}$ in which a truck driver stopped at the scene of a collision in which he was not involved, and was killed while carrying an injured child away from the accident. In awarding compensation, the Illinois Supreme Court approached the question as one of possible deviation, and concluded that the "deviation" to pick up the child was as much a natural incident of the job of truck driver as going across the street for a drink would be. It would be paradoxical indeed, as the court observed, if crossing the road to get a glass of beer could be held compensable, ${ }^{223}$ while crossing the road to pick up an injured child could not. Note that this reasoning echoed that in the Waters opinion: The rescue was a natural incident to be expected in the course of employment of this kind.

The rule at this point did not go so far as to say that every rescue of a stranger by an employee is covered; it referred to making a rescue the necessity for which is thrown in claimant's path by the distinctive conditions of his employment. When claimant is a worker in an area where construction and excavation are in progress, or a truck driver who is certain to encounter collisions along the highway, it is easy to see the connection between the work and the contact with the emergency. It will be observed that there is something of a parallel here to

221. 218 N.Y. 248,112 N.E. 727 (1916).

In the later case of Priglise v. Fonda, Johnstown \& Gloversville Railroad, 192 App. Div. 776, 183 N.Y.S. 414 (1920), the Appellate Division, an intermediate court, ignoring the broad principles announced by the Court of Appeals, held the rule of the case to be limited to the rescue of employees working on the same project-a factual limitation which, in terms of principle, makes no sense at all. The deceased was a flagman at a crossing of an electric railway, which paralleled a crossing of the New York Central having a gateman of its own. Some school children ran in front of an approaching New York Central train, in spite of the New York Central gateman's shouts, and deceased was killed trying to save one of the children. Compensation was denied, because, said the court, it was the other gateman's job to protect that crossing, and therefore it could not have been contemplated by deceased's employer that deceased should ever have to save children on the adjoining tracks. The court gave the deceased "the highest commendation" and "admiration for his heroism," but no money. Id. at 779, 183 N.Y.S. at 416.

222. 371 Ill. 497,21 N.E.2d 575 (1939).

223. See Martin v. John Lovibond \& Sons [1914] 2 K.B. 227. 
a similar stage in the stray-bullet story, when the necessity arose of expanding the street-risk concept to accommodate the situation of workers whose occupations were thought to involve special exposure to such risks.

It remained for the Supreme Court of the United States to extend the rescue doctrine to its ultimate limit, by covering the rescue of complete strangers when the connection with the employment is furnished, not by the nature of the employment, but solely by the fact that the employment brought the employee to the place where he observed the occasion for the rescue attempt. In O'Leary v. Brown-Pacific-Maxon, Inc., ${ }^{224}$ decedent was an employee of a governmental contractor operating on the island of Guam. The contractor maintained for its employees a recreation center near the shoreline, along which ran a channel so dangerous for swimmers that its use was forbidden, and signs to that effect were erected. Decedent had spent the afternoon at the center, and was waiting for his employer's bus to take him from the area when he saw or heard two men, standing on the reefs beyond the channel, signaling for help. Followed by nearly twenty others, he plunged in to effect a rescue. In attempting to swim the channel to reach the two men, he drowned. The Supreme Court, reversing the Ninth Circuit, ${ }^{225}$ ordered the award of compensation reinstated, three Justices dissenting. ${ }^{220}$

The Court's discussion of the reasons for this pioneering holding is in very brief and general terms: "The test of recovery is not a causal relation between the nature of employment of the injured person and the accident." ${ }^{227}$ Note that this sentence rules out at once any distinction between cases involving flagmen, truckers, and the like, and those involving ordinary employees who are not by the nature of their occupations brought in contact with emergency situations.

All that is required is that the "obligations or conditions" of employment create the "zone of special danger" out of which the injury arose. . . . A reasonable rescue attempt, like pursuit in aid of an officer making an arrest, may be "one of the risks of the employment, an incident of the service, foreseeable, if not foreseen, and so covered by the statute."228

224. 340 U.S. 504 (1951).

225. Brown-Pacific-Maxon, Inc. v. O'Leary, 182 F.2d 772 (9th Cir. 1950), rev'd, 340 U.S. 504 (1951).

226. The dissent was written by Mr. Justice Minton, joined by Mr. Justice Jackson and Mr. Justice Burton. 340 U.S. at 509.

227. Id. at 506-07.

228. Id. at 507. 
The Babington ${ }^{229}$ and Puttkammer ${ }^{230}$ cases, cited for this proposition, do not, however, support the novel contribution made by this case, since in both cases the character of the emergency was peculiarly associated with the character of the employment. The Babington case involved a cab driver who was pressed into the pursuit of a fugitive by a police officer; the Puttkammer case, as we have seen, involved a trucker who encountered a highway accident along the road.

It cannot be too strongly stressed that the Brown-Pacific-Maxon decision goes a crucial step beyond the Waters, Babington, and Puttkammer cases on which it relies. The Waters case contained general expressions broad enough to cover the Brown-Pacific-Maxon facts; but the actual Waters facts showed that the exigencies of the employment brought the rescuer and victim together in a dangerous place, namely, an excavation, where the character of the work might well be deemed to include the obligation to engage in rescue when slides or other mishaps occurred. The Brown-Pacijic-Maxon case adopts the positionalrisk theory in its purest form, by finding work-connection if the employment merely brings the employee to the place where he encounters a moral obligation to rescue a stranger. Presumably it would follow that an office worker who observed a street accident from a third-floor window would remain in the course of employment when rushing to aid the victims, since the employment would have provided the contact between the employee and the rescue opportunity.

The same week the Brown-Pacific-Maxon case was being argued, the Louisiana Court of Appeals denied an award in a case of this type, relying upon the Brown-Pacific-Maxon decision in the Ninth Circuit, which was on the verge of being reversed. In Edwards v. Louisiana Forestry Commission, ${ }^{231}$ a towerman in a forest observation tower saw a child being attacked by a dog near the foot of the tower. He hurried down the stairway and killed the dog, which proved to be rabid; but the exertion caused an inguinal hernia. The court summed up available precedents by saying: ". . . awards have been sustained in instances where some association between the act and the employment could be justified or where the service of the interest of the employer might be recognized."232

This employment probably could not be characterized as one which by its nature brings the employee in contact with rescue oppor-

229. Babington v. Yellow Taxi Corp., 250 N.Y. 14, 164 N.E. 726 (1928).

230. Puttkammer v. Industrial Comm'n, 371 Ill. 497, 21 N.E.2d 575 (1939).

231. 49 So. $2 d 53$ (La. App. 1950), rev'd, 221 La. 818 , 60 So. 2d 449 (1952).

232. 49 So. $2 \mathrm{~d}$ at 55 . 
tunities. In spite of the fact that his tower gives him a wide range of vision, the towerman is hardly in a position, in his remote perch in the forest, where the rescuing of privately-imperiled strangers might be deemed an incident of his kind of work. To cover this case, it was necessary to go the entire distance along the path blazed by the Supreme Court. Judge Kennon, dissenting, was prepared to adopt such a rule, in the following words:

It is my opinion that a workman, confronted by an emergency of the sort described, in which he is the only adult present to avert an impending danger to a fellow human being, particularly a child of tender years, has the right to take such action and to render such assistance as an ordinarily prudent person would do under the same circumstances, and that such action does not constitute a "turning aside" from his employer's business. ${ }^{233}$

After the United States Supreme Court decision was handed down, the $E d w a r d s$ case was reversed by the Supreme Court of Louisiana, ${ }^{234}$ relying both on the Brown-Pacific-Maxon case and on the Puttkammer case. It is a reasonable conclusion, then, that the rule in Louisiana may be taken to be that expressed in the quotation from Judge Kennon's dissent. The Supreme Court of Louisiana thus takes its place alongside the Supreme Court of the United States in applying the full positional-risk doctrine to rescue cases. This is an appropriate and consistent posture, since Louisiana pioneered in the development of the positional-risk doctrine in the more elementary category of tornadoes. ${ }^{235}$

New Jersey, which has also been in the forefront of the positionalrisk states, by virtue of such decisions as Gargiulo v. Gargiulo, ${ }^{230}$ the stray-arrow case, has also appropriately accepted the full implications of that doctrine in rescue situations. The decedent in Reilly v. Weber Engineering $\mathrm{Co}^{237}$ had worked as a fire captain in the city fire department, and had also worked for Weber three days a week. While engaged in his regular duties with Weber, decedent became aware of an emergency on some train tracks near Weber's premises. He went to

233. Id.

234. Edwards v. Louisiana Forestry Comm'n, 221 La. 818, 60 So. 2d 449 (1952). Although the decision was set aside on rehearing on the ground that a decision on the merits was premature, the opinion clearly indicates the intention of the Louisiana Supreme Court to follow the broad rescue rule accepted by the Supreme Court of the United States. Id. at 834,60 So. $2 \mathrm{~d} 457$.

235. Harvey v. Caddo De Soto Cotton Oil Co., 199 La. 720, 6 So. $2 d 747$ (1942).

236. 12 N.J. 607, 97 A.2d 593 (1953).

237. 107 N.J. Super. 254, 258 A.2d 36 (1969). 
assist in helping a young boy who had been caught in some electrical wires, and while doing so was killed. His death was held to be compensable, on the grounds that the rescue attempt was within the scope of decedent's employment, and that but for the fact of the employment with Weber the death would not have occurred. Although the facts included one item that might have supplied a small morsel of special work-connection-the fact that the secretary of the company's president had asked to have the cause of the commotion investigated-the court put the result on strictly positional-risk grounds. ${ }^{238}$ Just as the employment brought Gargiulo "into the line of fire of the arrow, where he would not have been but for his employment," so the employment brought Reilly into the range of a call for rescue where he would not have been but for his employment.

Minnesota had an opportunity to join this advance guard, but declined it, in the case of Weidenbach v. Miller. ${ }^{239}$ The deceased, a truck driver, accompanied by his employer, was driving along a lake, the shore of which followed the highway. They observed a man floundering in the lake. The employer said in effect, "There is a man in the lake. We had better stop." The deceased stopped the truck, leaped over a fence and went on to the frozen lake. While he was attempting the rescue, the ice gave way and he drowned. The employer had followed and called to deceased to return because the ice was thin. He had also tried to reach deceased with a limb after he had fallen through. The court, after noting numerous cases, observed that awards have been made when the act was incidental to the employment, in the sense that assistance to injured people on the highway is an incident of truck driving. But since the stranger to be rescued here was not on the highway the court stated the issue to be:

Can it be said that assistance to any person observed to be in peril off the highway, regardless of the distance separating such person from the highway is incidental to the employment so long as such person is within the range of the employee's vision?240

The court answered in the negative, and affirmed the Commission's denial of compensation. As to the contention that the employer enlarged the employment scope by ordering the rescue, the court stated that there was no express direction to go to the aid of a stranger: "At

238. The court quotes with approval the writer's characterization of Brown-PacificMaxon as an adoption of "the positional risk theory in its purest form." Id. at 261, 258 A.2d at 40, quoting 1 A. LARSON, WORKMEN's COMPENSATION LAW $\$ 28.23$ at 452.85 (1966).

239. 237 Minn. 278, 55 N.W.2d 289 (1952).

240. Id. at 291,55 N.W.2d at 296. 
best the employer inquired of the employee whether they should not do so." 241

The court attempted to distinguish the $O$ 'Leary case on the basis, first, that the Commission had there awarded compensation; and second, that the "zone of danger", that is, the channel in which the employee had lost his life, was adjacent to the recreation center. Thus, said the court, it was reasonably foreseeable that someone might venture into the danger zone and that those using the recreation center might go to the rescue.

These two grounds of distinction are somewhat less than convincing. As to the first, the question whether the Commission had initially awarded or denied compensation would be important if the issue had been one of fact; but here the issue was not only one of law-it was the kind of ground-breaking legal question for which courts of last resort have a peculiarly pressing responsibiliy to play their part in the development of compensation law. As to the second ground of distinction, that the conditions of O'Leary's employment brought him near the body of water which proved to be a zone of danger, and that it was reasonably foreseeable that someone might venture into the danger zone, the same could be said with equal force of the facts in the Weidenbach case. The state of Minnesota has been at great pains to drill into the consciousness of every American the fact that Minnesota is the land of the 10,000 lakes. Indeed, some say that the actual number is higher, but then much depends on one's definition of a lake. In any event the court could readily and properly have taken judicial notice of this fact, with the corollary fact that anyone driving a truck in Minnesota is certain to be driving alongside lakes frequently. As for the foreseeability of seeing people venturing out onto these lakes, there is no reason to suppose that the disposition of human beings to go out onto bodies of water and get into trouble is any more highly-developed in Guam than in Minnesota. Most lakes in Minnesota are just as much recreational areas as the area involved in the O'Leary case-more so, in fact, since the particular area in the O'Leary case had been banned for recreational use, while the Minnesota lakes are freely open for swimming, boating, skating, and both summer and winter fishing.

The distinctions between the two cases, such as they are, make the Minnesota case a stronger one for compensation. The truck driver was actively working at the time of the rescue opportunity; O'Leary was engaged in recreation. The truck driver became originally involved

241. Id. at $292-93,55$ N.W.2d at 297. 
in the rescue by stopping at his employer's suggestion, and his employer did not prevent at least the initiation of the attempt; O'Leary entered an area which his employer had forbidden anyone to enter.

The distinction drawn by the Minnesota court between a rescue opportunity in the form of an accident on the highway itself, and one in the form of an accident visible from the highway but not on it, has the same brittle arbitrary quality of the Minnesota decision which held that injury by a stray bullet was not compensable because, having occurred on a vacant lot between a garage and office building rather than on a genuine street, it was not a "street risk." ${ }^{42}$ This kind of fact-categorical approach to compensation law cannot survive long when there is no real distinction in principle. There is only one valid operative principle at work here: The employment thrust the employee into contact with a situation in which it was natural and probable that he as a human being would make the rescue attempt. If it had not been for the conditions and obligations of the employment, this demand upon the employee's natural human reactions would never have been made and he would not have lost his life. More than this compensation law should not require.

\section{Conclusion}

It was observed at the outset that the positional-risk doctrine could not as yet be accorded majority rule status, but that it had enlisted an impressive and growing roster of adherents. On the strength of the analysis just concluded, one may now essay a somewhat more specific appraisal of the size of this roster.

Using as a guide either the adoption of the positional-risk rule by name, or the application of it in practice, or both, one is entitled to conclude that at least thirteen jurisdictions, have accepted the positionalrisk principle: Colorado, Louisiana, New Jersey, Kentucky, California, Massachusetts, New York, Texas, the Circuit Court of Appeals for the District of Columbia, Hawaii, Idaho, South Dakota, Oklahoma, and the United States Supreme Court.

A brief comment on each of these entries will indicate why they have been included.

Colorado was the first positional-risk state, ${ }^{243}$ and, starting with a lightning case, ${ }^{244}$ has generalized the principle to support awards in a

242. Auman v. Breckenridge Tel. Co., 188 Minn. 256, 246 N.W. 889 (1933).

243. See note 3 supra.

244. Aetna Life Ins. Co. v. Industrial Comm'n, 81 Colo. 233, 254 P. 995 (1927). 
lunatic-assault case ${ }^{245}$ and an unexplained-assault case. ${ }^{240}$

Louisiana has carried the principle the furthest of all, and indeed, as indicated earlier, has even overshot the mark somewhat by disregarding the "neutral-risk" limitation of the rule in personal-assault cases. $^{247}$ Louisiana has clearly and repeatedly approved the positionalrisk doctrine in making awards for injuries as the result of tornadoes, ${ }^{248}$ stray bullets, ${ }^{249}$ personal assaults, ${ }^{250}$ and rescue of strangers. ${ }^{251}$

New Jersey also ranks. high among the supporters of the doctrine, having applied it to such diverse hazards as a stray arrow, ${ }^{252}$ a kitchen cabinet, ${ }^{253}$ a personal but non-private assault, ${ }^{254}$ an unexplained fall, ${ }^{255}$ and a rescue of a stranger. ${ }^{256}$

Kentucky has invoked the doctrine in a lunatic-assault case, ${ }^{257}$ an unexplained-assault case, ${ }^{258}$ and a falling-tree case, ${ }^{259}$ and has fortified its claim to membership in this group by its explicit adoption of the positional-risk rule by name in the first of these cases.

California's place on the list rests on a stray-bullet case, ${ }^{260}$ in which the court made a conscious choice of the positional-risk principle over the less daring option of the "contact-with-the-premises" rule.

Massachusetts also has followed the doctrine in a stray-bullet case $^{261}$ - which is in some ways the most classic form of neutral riskand had also earlier accepted this approach in an unexplained-assault award. ${ }^{262}$

New York, while never quite coming right out and announcing the adoption of the positional-risk rule by name, has probably pro-

245. London Guar. \& Accident Co. v. McCoy, 97 Colo. 13, 45 P.2d 900 (1935).

246. Industrial Comm'n v. Ernest Irvine, Inc., 72 Colo. 573, 212 P. 829 (1923).

247. See text accompanying notes 174-75 supra.

248. Harvey v. Caddo DeSoto Cotton Oil Co., 199 La. 720, 6 So. $2 d 747$ (1942).

249. Williams v. United States Cas. Co., 145 So. 2d 592 (La. App. 1962).

250. Rogers v. Aetna Cas. and Sur. Co., 173 So. 2d 231 (La. App. 1965); Gormings v. Edwards, 222 So. 2d 530 (La. App. 1969).

251. Edwards v. Louisiana Forestry Comm'n, 221 La. 818, 60 So. $2 d 449$ (1952).

252. Gargiulo v. Gargiulo, 13 N.J. 8, 97 A.2d 593 (1953).

253. Brooks v. Dee Realty Co., 72 N.J. Super. 499, 178 A.2d 644 (1962).

254. Crotty v. Driver Harris Co., 49 N.J. Super. 60, 139 A.2d 126 (1958); Martin v.

J. Lichtman \& Sons, 42 N.J. 81, 199 A.2d 241 (1964).

255. Spindler v. Universal Chain Corp., 11 N.J. 34, 93 A.2d 171 (1952).

256. Reilly v. Weber Eng'r Co., 107 N.J. Super. 254, 258 A.2d 36 (1969).

257. Corken v. Corken Steel Prods., Inc., 385 S.W.2d 949 (Ky. App. 1965).

258. Coomes v. Robertson Lumber Co., 427 S.W.2d 809 (Ky. App. 1968).

259. Kaycee Coal Co: v. Short, 450 S.W.2d 262 (Ky. App. 1970).

260. Industrial Indem. Co. v. Industrial Accident Comm'n, 95 Cal. App. 2d 805, 214

P.2d 41 (1950).

261. Baran's Case, 336 Mass. 342, 145 N.E.2d 726 (1957).

262. McLean's Case, 323 Mass. 35,80 N.E.2d 40 (1948). 
duced in effect more positional-risk awards than any other jurisdiction. The categoties include: stray bullets, ${ }^{263}$ flying debris, ${ }^{264}$ insect bites, ${ }^{265}$ injury by the talons of a flying owl, ${ }^{266}$ falling trees, ${ }^{207}$ unexplained assaults, ${ }^{268}$ and unexplained falls. ${ }^{269}$

Texas law has produced awards reflecting the positional-risk approach in a wasp-sting case, ${ }^{270}$ a lunatic-assault case, ${ }^{271}$ and an unexplained-assault case. ${ }^{272}$

The Circuit Court of Appeals for the District of Columbia has definitely been a leader in the positional-risk movement, with its opinions on cases involving lunatic assaults, ${ }^{273}$ unexplained falls, ${ }^{274}$ and personal but non-private assaults. ${ }^{275}$

Hawaii's acceptance of the doctrine seems clear from the rationale adopted in a lunatic-assault case. ${ }^{276}$

Idaho also has employed the principle in a lunatic-assault case, ${ }^{277}$ as well as in an unexplained-assault situation. ${ }^{278}$

South Dakota's inclusion in this group appears justified by its opinion awarding compensation in what is perhaps the closest of all positional-risk problems, that of a personal assault not traceable to the parties' private lives. ${ }^{279}$

Oklahoma is also listed here, on the strength of a recent unexplained-assault case, particularly because of the explicit approval by the Oklahoma Supreme Court of the thesis here advanced as to unexplained assaults, falls, and deaths. ${ }^{280}$

263. See Christiansen v. Hill Reprod. Co., 262 App. Div. 379, 29 N.Y.S.2d 24, aff'd, 287 N.Y. 690, 39 N.E.2d 300 (1942). See notes 59-65 supra and accompanying text.

264. Filitti v. Lerode Homes Corp., 244 N.Y. 291, 155 N.E. 579 (1927); Malena v. Leff, 265 N.Y. 533, 193 N.E. 307 (1934).

265. Webster v. Mason, 13 App. Div. 2d 355, 217 N.Y.S.2d 290 (1961); Richmond v. Mass. \& Birzt, 275 App. Div. 879, 88 N.Y.S.2d 682 (1949).

266. Avis v. Electrolux Corp., 2 App. Div. 2d 717, 151 N.Y.S.2d 542 (1956).

267. Monahan v. Remington Rand, Inc., 9 App. Div. 2d 810, 192 N.Y.S.2d 900 (1959).

268. Fox v. Carpenters Local 606, 33 App. Div. 2d 605, 304 N.Y.S.2d 464 (1969).

269. Martin v. Plaut, 293 N.Y. 617, 59 N.E.2d 429 (1940). See note 176 supra (New York cases).

270. Travelers Ins. Co. v. Williams, 378 S.W.2d 110 (Tex. Civ. App. 1964).

271. Travelers Ins. Co. v, Hampton, 414 S.W.2d 712 (Tex. Civ. App. 1967).

272. Casualty Reciprocal Exch. v. Johnson, 148 F.2d 228 (5th Cir. 1945).

273. Hartford Accident \& Indem. Co. v. Hoage, 85 F.2d 417 (D.C. Cir. 1936).

274. New Amsterdam Cas. Co. v. Hoage, 62 F.2d 468 (D.C. Cir. 1932).

275. Hartford Accident \& Indem. Co. v. Cardillo, 112 F.2d 11 (D.C. Cir. 1940).

276. Asaeda v. Haraguchi, 37 Hawaii 556 (1947).

277. Louis v. Bamboo Gardens, 67 Idaho 469, 185 P.2d 712 (1947).

278. Mayo v. Safeway Stores, Inc., 93 Idaho 161, 457 P.2d 400 (1969).

279. Anderson v. Hotel Cataract, 70 S.D. 376, 17 N.W.2d 913 (1945).

280. B \& B Nursing Home v. Blair, 496 P.2d 795 (Okla. 1972). 
Finally the Supreme Court of the United States is appropriately associated with these jurisdictions, in the light of its application of the positional-risk principle to the rescue of a stranger. ${ }^{281}$

In addition to this group, there may be mentioned several states in which the acceptance of the positional-risk approach is marginal or inconclusive, because it rests on awards for unexplained risks. North Dakota $^{282}$ and New Mexico ${ }^{283}$ have made awards for unexplained assaults, and Connecticut, ${ }^{284}$ Florida, ${ }^{285}$ Georgia, ${ }^{286}$ and North Carolina ${ }^{287}$ have made awards for unexplained falls. However, as discussed in connection with unexplained deaths, although in a lesser degree, there may be other factors at work in these decisions that keep them from standing as clean-cut commitments to the positional-risk principle. When a court makes an award in, say, a simple stray-bullet case, there is almost no way in which that decision can avoid constituting outright endorsement of the positional-risk rule. By contrast, in the "unexplained" cases, the inference is not so inescapable, since there may be other arguments, such as presumptions of compensability, that blunt the edge of the holding.

Nevertheless, it can always be argued that what is unexplained is neutral, and from this premise the unexplained-fall and unexplainedassault cases, and even to some extent the unexplained-death cases, may serve to open the door to the positional-risk principle in a number of states.

The purpose of the present analysis has been, not only to show how far the positional-risk doctrine has progressed, but also to demonstrate that it is and should be a pervading rule of causal relation, not confined to any single factual category, but relevant to every risk that can be called "neutral," including the unexplained risks. It is gratifying to note that almost all jurisdictions that have dealt with the question have accepted this view. The simplest and most obvious application is exemplified by Michigan's ready acceptance of the fact that, in adopting the positional-risk rule for a tornado award, ${ }^{288}$ it necessarily had to overrule a line of increased-risk lightning cases. ${ }^{289}$ Although a

281. O'Leary v. Brown-Pacific-Maxon, Inc., 340 U.S. 504 (1951).

282. Lippman v. Workmen's Comp. Bureau, 79 N.D. 248, 55 N.W.2d 453 (1952).

283. Ensley v. Grace, 76 N.M. 691, 417 P.2d 885 (1966).

284. Ryerson v. A.E. Bounty Co., 107 Conn. 370, 140 A. 728 (1928).

285. Damon v. Central Hotel, 135 So. $2 d 204$ (Fla. 1961).

286. American Mut. Liab. Ins. Co. v. King, 88 Ga. App. 176, 76 S.E.2d 81 (1953).

287. Robbins v. Bossong Hosiery Mills, 220 N.C. 246, 17 S.E.2d 20 (1941).

288. Whetro v. Awkerman, 383 Mich. 235, 174 N.W.2d 783 (1970).

289. See note 35 supra. 
little less obvious, the carry-over between such risks as lightning and unexplained falls has also been generally recognized, as in the pioneering but short-lived Indiana contribution to positional-risk history. ${ }^{290}$ That this carry-over is not always seen as self-evident, however, is shown by the fact that Colorado, more than forty years after it launched the positional-risk era, was still capable of denying compensation in a straight unexplained-fall case. ${ }^{291}$

In judging the vigor and pace of the growth of the positional-risk principle, one must bear in mind that the kind of fact situation that forces a court to take a stand on this principle is relatively rare. The vast majority of cases can be disposed of by finding some morsel of increased risk, for example, creating a slightly greater hazard of exposure to lightning than that of the general public, or by taking refuge in some half-way house such as a street-risk doctrine or the contactwith-the-premises exception. Looked at from this angle, the story is significant for the scarcity of cases in which a court will hold the positional-risk up to view and then specifically reject it, as Missouri, for example, has done. ${ }^{292}$ More common is the practice of considering the doctrine and then concluding that, since the award can in any event be affirmed on a less innovative theory, the court will not break new ground when the case in hand does not require it. ${ }^{293}$

In conclusion, then, it seems a safe prediction that, as true neutralrisk cases come before appellate courts for decision, the present strong momentum of the positional-risk doctrine will before long carry it to the point where it can be awarded the title of majority rule.

290. See text accompanying notes 26-31 supra.

291. Finn v. Industrial Comm'n, 165 Colo. 106, 437 P.2d 542 (1968). See note 211 supra.

292. Lathrop v. Tobin-Hamilton Shoe Mfg. Co., 402 S.W.2d 16 (Mo. Ct. App. 1966).

293. See, e.g., W.T. Edwards Hosp. v. Rakestraw, 114 So. $2 d 802$ (Fla. App. 1959), where Florida followed this course.

The holding by the Supreme Court of Indiana in its affirmance of E.I. DuPont de Nemours Co. v. Lilly, 75 N.E.2d 796 (Ind. App. 1947), aff'd, 226 Ind. 267, 79 N.E.2d 387 (1948), was also of this character, but, as indicated in the text at that point, was misinterpreted by the appellate court as a rejection of the positional-risk theory. 
